\title{
Miscanthus: a case study for the utilization of natural genetic variation
}

\author{
T. R. Hodkinson ${ }^{1,2 *}$, M. Klaas ${ }^{3}$, M. B. Jones ${ }^{1}$, R. Prickett ${ }^{1}$ and S. Barth ${ }^{3}$ \\ ${ }^{1}$ School of Natural Sciences, Trinity College Dublin, Dublin D2, Ireland, ${ }^{2}$ Trinity Centre \\ for Biodiversity Research, Trinity College Dublin, Dublin D2, Ireland and ${ }^{3}$ Teagasc Crops \\ Environment and Land Use Programme, Oak Park Research Centre, Carlow, Ireland
}

Received 28 May 2014; Accepted 25 September 2014 - First published online 12 November 2014

\begin{abstract}
Cultivars of Miscanthus used as bioenergy crops or tested in trials are largely clonally propagated, wild sourced genotypes or clonally propagated F1 hybrids. One of the most productive taxa is the sterile triploid $M . \times$ giganteus. Little domestication or breeding has been undertaken and there is huge potential to utilize the extensive genetic resources of the genus for crop improvement. The challenge is to generate new highly adapted genotypes suitable for a range of environments. Production on marginal land, not used for food crops, is particularly desirable, but presents many barriers to crop breeders, as these are largely unproductive and/or stressful environments. This article outlines progress made in characterizing natural genetic variation in Miscanthus including next-generation single-nucleotide polymorphism genotyping, quantitative trait locus analysis and association mapping. It also explains how this knowledge is being used to develop novel genotypes suited for growth in a broad range of agricultural and marginal lands by defining breeding pools, generating novel crosses, manipulating polyploidy and applying genomic selection approaches.
\end{abstract}

Keywords: adaptive variation; association mapping; genome size; genomic selection; Miscanthus; phylogeny; ploidy

\section{Introduction}

Miscanthus is a perennial rhizomatous grass genus that is currently under intense development as a bioenergy crop. It has, since the late 1970s, come to the attention of the plant breeding community for energy and fibre (1970s onwards; Jones and Walsh, 2001) and is hence considered undomesticated (Yan et al., 2012; Slavov et al., 2014). Cultivars of Miscanthus used as crops or tested in trials are largely clonally propagated (singlegenotype), wild sourced material or clonally propagated F1 hybrids (Hodkinson et al., 2002c; Głowacka et al., $2014 a$, b). There is a need to generate new broadly adapted genotypes suitable for a range of environments including both agricultural and marginal lands

\footnotetext{
*Corresponding author. E-mail: Trevor.Hodkinson@tcd.ie
}

(Clifton-Brown et al., 2008; Chou, 2009; Jørgensen, 2011; Qin et al., 2011; Jing et al., 2012; Nijsen et al., 2012). There is a movement towards developing crops suited for marginal land so that fertile land is not taken away from food production (Cai et al., 2011; Donnelly et al., 2011; Gopalakrishnan et al., 2013). For example, the EU FP7 project GrassMargins aims to develop genotypes suitable for growth on European marginal land (http://www.grassmargins.com). Furthermore, China possesses 100 million hectares of marginal and degraded land, especially in the northern and western regions, that has the potential to produce approximately 1 billion tons of Miscanthus feedstock (Sang, 2011; Sang and Zhu, 2011). To achieve this potential, many plant traits will need to be optimized including yield, flowering, drought tolerance, frost and cold tolerance, and biomass chemical composition (reviewed in Jones et al. (2014)).

Miscanthus breeding is a case study of genetic resource utilization for novel crop development. 
The genus has a wealth of genetic resources, and the progress made in characterizing and utilizing this diversity is outlined in this review. We do not consider reverse-genetic studies and genetic engineering approaches for crop development here. Such details can be found elsewhere (Wang et al., 2011; Xie and Peng, 2011; Feltus and Vandenbrink (2012); Perera et al., 2013). We instead focus on the problems and prospects of using natural genetic variation for Miscanthus crop production. Much progress has been made on the fundamental characterization of Miscanthus species such as on their taxonomy and phylogenetics. Furthermore, several studies have outlined population genetic variation and examined adaptive variation of a range of genotypes. The ongoing challenge is to combine the genotypic and phenotypic knowledge for crop development and to better incorporate natural genetic diversity into breeding programmes. Next-generation sequencing and breeding technologies utilizing association studies and genomic selection (GS) offer considerable potential in this respect. Although many genetic resource collections of Miscanthus exist in Europe and the Americas outside of Asia, there is neither a directory of Miscanthus collections nor a coordinated programme for the conservation of its genetic resources.

\section{Taxonomy, phylogeny and distribution}

Miscanthus sensu lato (s.l., in the broad sense) includes about 20 species depending on the author (Clayton and Renvoize, 1986; Scally et al., 2001a, b; Clayton et al.,
2006 onwards). However, its generic limits have been revised based on molecular phylogenetics (Hodkinson et al., 1997, 2002a; Swaminathan et al., 2010). DNA sequences and fingerprinting data reported by Hodkinson et al. (2002a, b) showed that some species included in Miscanthus s.l. are more closely related to other genera than to Miscanthus. Miscanthus sensu stricto (s.s., in the strict sense) includes only those species with a basic chromosome number of 19. Its taxonomic type species is $M$. floridulus (Labil.) Warb. (=M. japonicus Anderss; basionym Saccharum floridulum Labillardière described in 1824).

Synonymy is high in the genus. The International Plant Names Index (IPNI, 2014) lists over 60 species, but only 11-12 species can be recognized in Miscanthus s.s. (Table 1). Although hybridization is known to occur within the genus, few hybrids have been identified and named despite the lack of breeding barriers and the sympatry of several taxa. Miscanthus $\times$ giganteus Greef et Deuter ex Hodkinson and Renvoize was described by Hodkinson and Renvoize (2001). They showed that the name $M . \times$ giganteus Greef et Deuter is illegitimate because neither the type was specified nor a Latin description was provided. They chose to keep the species epithet $\times$ giganteus to prevent confusion in the literature, but updated the authority names accordingly. New records of natural hybridization between M. sacchariflorus and M. sinensis have been reported (Nishiwaki et al., 2011). The name Miscanthus ogiformis is not correctly applied to Miscanthus $\times$ giganteus as it does not recognize the hybrid nature of the taxon and

Table 1. List of Saccharinae genera and species belonging to Miscanthus s.s.

\begin{tabular}{ll}
\hline Saccharinae (Andropogoneae and Panicoideae; & \\
Clayton and Renvoize (1986)) & Miscanthus s.s. \\
\hline Eriochrysis P. Beauv (7 spp.) & M. floridulus (Labil.) Warb. ex K. Schum. \& Lauterb. [type] \\
Eulalia Kunth (30 spp.) & M. intermedius (Honda) Honda \\
Eulaliopsis Honda (2 spp.) & M. longiberbis Nakai \\
Homozeugus Stapf. (5 spp.) & M. lutarioriparius L.Liu ex Renvoize \& S.L. Chen ${ }^{\text {a }}$ \\
Imperata Cyr. (8 spp.) & M. oligostachyus Stapf. \\
Lophopogon Hack. (2 spp.) & M. paniculatus (B.S. Sun) Renvoize \& S.L. Chen \\
Microstegium Nees (15 spp.) & M. sacchariflorus (Maxim.) Hack. \\
Miscanthus Anderss. (20 spp.) & M. sinensis Anderss. \\
Pogonatherum P. Beauv. (3 spp.) & M. tinctorius (Steud.) Hack. \\
Saccharum L. (35-40 spp; & M. transmorrisonensis Hayata \\
here including Erianthus) & M. $\times$ giganteus Greef et Deuter ex Hodkinson and Renvoize \\
Spodiopogon Trin. (9 spp.) & \\
Polytrias Hack. (1 sp.) & \\
Polliniopsis (1 sp.) & \\
Diandranthus & \\
Miscanthidium & \\
Sclerostachya & \\
spp., species. & \\
a Likely to be an infraspecific taxon of M. sacchariflorus.
\end{tabular}


cannot be linked to the type (Ibaragi et al., 2013). Miscanthus floridulus and M. sinensis also have sympatric distributions and similar morphology. Phenotypic evaluation of these show that the two species intergrade in their morphology and that hybrids are potentially common (Scally et al., 2001a). There is clearly a need for more research on natural hybrids and hybrid zones in Miscanthus and the taxonomic treatment of these taxa.

Miscanthus is classified in the predominantly tropical grass tribe Andropogoneae and subtribe Saccharinae (Clayton and Renvoize, 1986; Clayton et al., 2006 onwards; Bouchenak-Khelladi et al., 2008; Teerawatananon et al., 2011; Kellogg, 2013). Saccharinae includes the sugarcane genus Saccharum L. s.l. and several less well-known genera (Table 1). The term 'Saccharum complex' has been used to describe a taxonomically difficult subset of Saccharinae (Erianthus, Miscanthus, Narenga, Saccharum and Sclerostachya) implicated in the origin of sugarcane (Daniels and Roach, 1987). Miscanthus species are unusual among Andropogoneae because they have bisexual paired spikelets, both with hermaphrodite flowers (Fig. 1). Other Andropogoneae have paired spikelets, but with the exception of a few genera such as Ischaemum L. and Schizachyrium Nees, one of these is usually male or sterile (Clayton and Renvoize, 1986).

Morphological descriptions of Miscanthus are included in several floras including Chen and Renvoize (2006) for China, Koyama (1987) and Osada (1993) for Japan, Cope (1982) for Pakistan, Gilliand (1971) for Malaya and Hodkinson (submitted) for Thailand. Miscanthus species are perennial and rhizomatous (Fig. 1) with erect canelike stems growing up to $7 \mathrm{~m}$ tall (in $M$. lutarioriparius = M. sacchariflorus). They are sometimes tufted with short rhizomes. The inflorescence is terminal and bears plumose racemes. Its spikelets are pedicellate and paired (one with a short pedicel and another with a long pedicel). The inflorescence axis may be long and have relatively short racemes as in $M$. floridulus or may be (a)

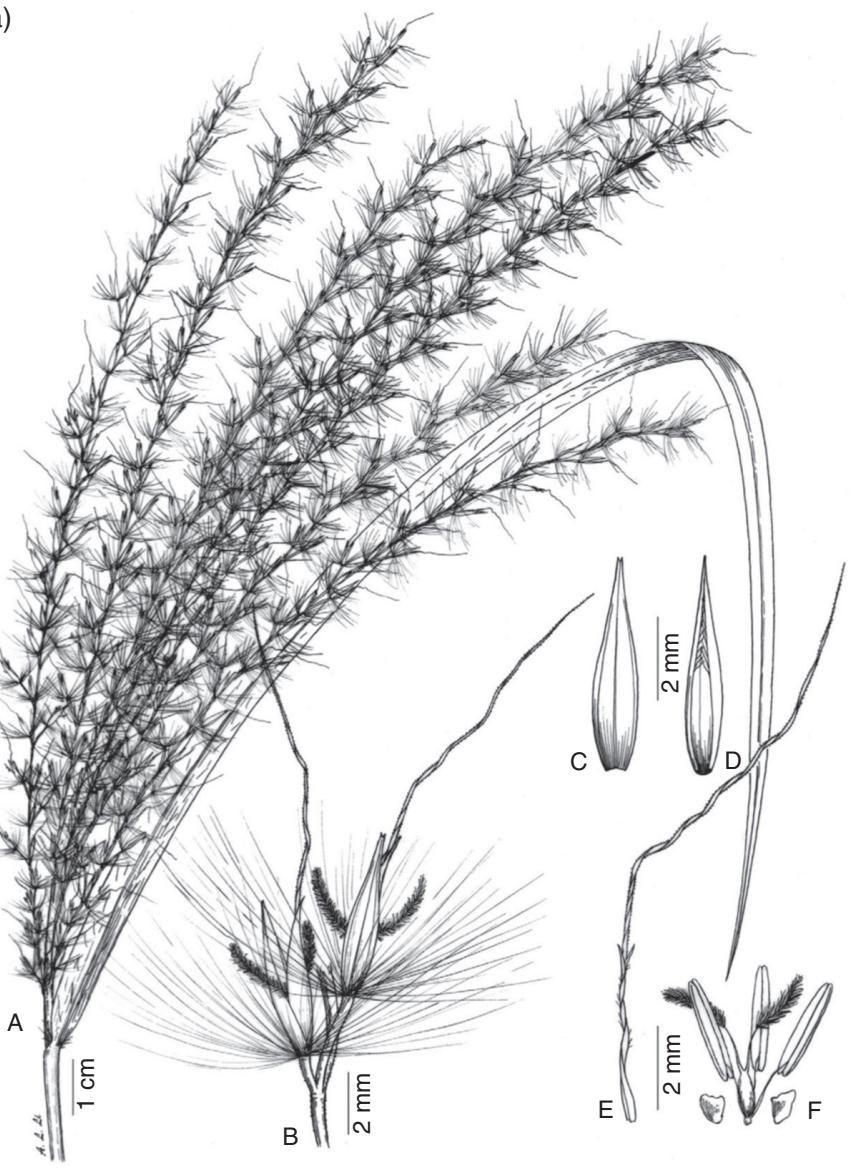

(b)

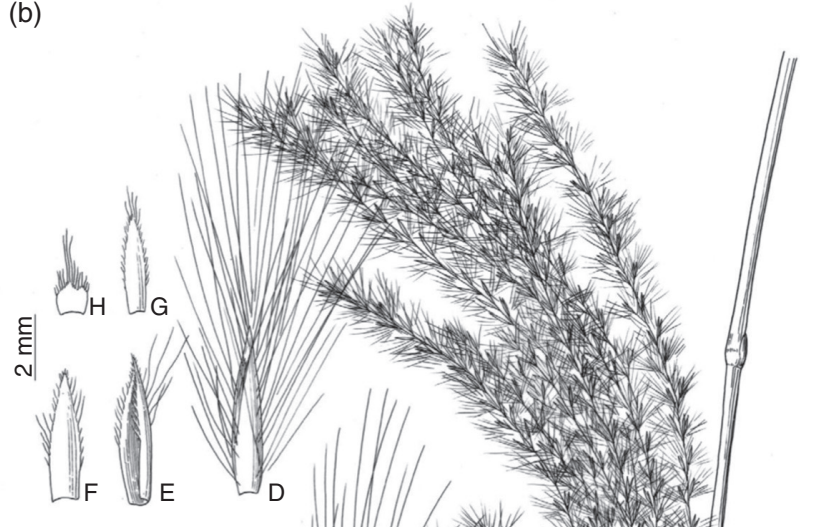

Fig. 1. Line drawings of (a) Miscanthus sinensis and (b) M. sacchariflorus (from Sun et al. (2010), with permission). (a) A, Panicle and leaf; B, paired spikelets; C, back of a lower glume; D, ventral side of an upper glume; $E$, ventral side of an upper lemma with awn; and F, stamens and gynoecium. (b) A, Rhizome and culm; B, panicle and leaf; C, paired spikelets; $\mathrm{D}$, back and ventral sides of a lower glume; $\mathrm{E}$, ventral side of an upper glume; F, back of a lower lemma; G, back of an upper lemma without awn; and $\mathrm{H}$, lodicule. 
short with long racemes (subdigitate inflorescence, as in most M. sinensis and M. sacchariflorus; Fig. 1).

Some comparative morphological and anatomical studies have been published on Miscanthus (Lee 1964a, b, c, d; Scally et al., 2001a, b; Sun et al., 2010). These studies helped define species boundaries, improved infrageneric classification and quantified morphological variation. Important diagnostic characteristics are found in inflorescence axis length, raceme length and number, spikelet size, spikelet callus hair length, glume and lemma size, nerves on glumes, dorsal hairs of glume, and presence or absence of awns (Lee 1964a, b, c, d; Scally et al., 2001a, b; Chen and Renvoize, 2006). For example, Scally et al. (2001a, b) used 31 morphological characteristics predominantly from spikelets and the inflorescence to study variation in Miscanthus species using principal component analysis and detrended correspondence analysis. Miscanthus sacchariflorus and M. sinensis were clearly differentiated with these methods, but the other species clustered with the $M$. sinensis group. There is huge morphological variation present in $M$. sinensis. A standardized list of morphological descriptors has not yet been published, but would be of high value for phenotyping studies (Scally, 2001; De Cesare, 2012).

Groups of species at sectional rank within Miscanthus have been described and keys to Miscanthus species provided by Hodkinson et al. (1997) and Chen and Renvoize (2006). The most comprehensive effort to taxonomically subdivide the genus was made by Lee (1964a, b, c, d), who separated the genus into four sections. Three can be assigned to Miscanthus s.s. (sections Kariyasua, Miscanthus and Triarrhena) and one (section Diandra) is not part of Miscanthus s.s. because of DNA sequence evidence (Hodkinson et al., 2002a) and chromosome number (Fig. 4; Table 2). Section Diandra species also have two anthers compared with three anthers in Miscanthus s.s. Other species assigned to Miscanthus s.l. are better included in Miscanthidium (an African taxon; M. ecklonii, M. junceus and M. sorghum, M. violaceus), Sclerostachya fusca and Diandranthus (various combinations including $M$. nepalensis and $M$. nudipes) (Hodkinson et al., 2002a).

Miscanthus s.s. is native to Eastern Asia, Southeastern Asia and the South Pacific (Fig. 2), with the highest species diversity being recorded in Eastern Asia, especially in China and Japan (Chen and Renvoize, 2006; Sun et al., 2010). Its native latitudinal range extends from temperate Southeast Russia at $50^{\circ} \mathrm{N}$ to tropical Polynesia at $22^{\circ} \mathrm{S}$. Its native longitudinal distribution extends from Burma and Andaman and Nicobar Islands at $92^{\circ} \mathrm{E}$ to $\mathrm{Fiji}$ at $179^{\circ} \mathrm{W}$. Its species have radiated to occupy a wide range of biomes and

Table 2. List of chromosome studies carried out on the $x=19$ Miscanthus S.s. taxa ${ }^{a}$

\begin{tabular}{|c|c|c|}
\hline Taxons & $2 n$ and ploidy & Published ploidy counts \\
\hline M. $\times$ giganteus & $\begin{array}{l}2 n=3 x=57,58^{\mathrm{b}} \\
\text { Allotriploid }\end{array}$ & $\begin{array}{l}\text { Adati and Mitsuishi (1956); Adati (1958); Linde-Laursen (1993); } \\
\text { Lafferty and Lelley (1994); Hodkinson et al. (2001, 2002c) }\end{array}$ \\
\hline M. intermedius & $\begin{array}{l}2 n=6 x=114 \\
\text { Allohexaploid }\end{array}$ & Adati and Mitsuishi (1956); Adati (1958) \\
\hline \multirow{2}{*}{$\begin{array}{l}\text { M. sinensis ssp. } \\
\text { condensatus }\end{array}$} & $2 n=2 x=38$ & Hodkinson et al. $(2001,2002 a, b, c)$ \\
\hline & $2 n=3 x=57$ & Adati and Mitsuishi (1956); Adati (1958); Hirayoshi et al. (1959) \\
\hline M. lutarioriparius & $2 n=4 x=76$ & Li et al. $(2013)^{\mathrm{c}}$ \\
\hline & $2 \mathrm{n}=5 \mathrm{x}=95$ & \\
\hline \multirow[t]{3}{*}{ M. tinctorius } & $2 n=2 x=38$ & Adati and Mitsuishi (1956); Adati (1958); Hirayoshi et al. (1959) \\
\hline & $2 n=4 x=76$ & \\
\hline & $2 n=6 x=114$ & \\
\hline
\end{tabular}

\footnotetext{
a Several other taxa classified as Miscanthus s.l. do not share a basic chromosome number of 19; they are more commonly based on 10 or 15 such as M. fuscus, $n=15$ (Li, 1959); M. nepalensis, $n=20$ (Mehra et al., 1968); M. nudipes, $n=20$ (Mehra et al., 1968); Miscanthidium violaceum, $n=14$ (Brett, 1954); and Narenga porphyrocoma, $n=15$ (Burner et al., 1991). ${ }^{b}$ Linde-Laursen recorded mostly 58 chromosomes with some at $57 .{ }^{c}$ Based on flow cytometry.
} 


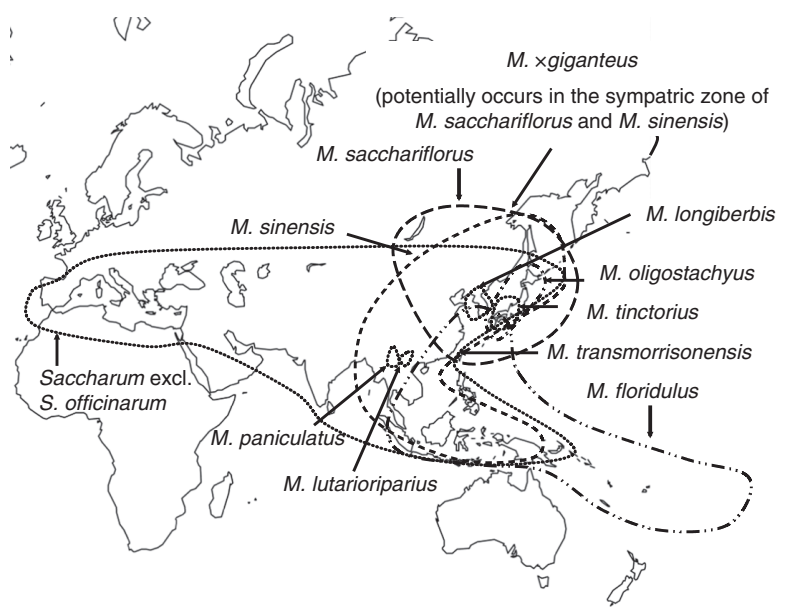

Fig. 2. Geographical distribution of Miscanthus s.s. species (from Clifton-Brown et al. (2008), with permission). The range of $M . \times$ giganteus is not known, but can potentially occur in sympatric regions of $M$. sinensis and $M$. sacchariflorus. The distribution of $M$. intermedius (Japan) is not shown.

climatic zones. Some species such as M. floridulus generally grow at sea level or in warm tropical climates, but others such as $M$. paniculatus can tolerate high altitudes of up to $3100 \mathrm{~m}$ on dry mountain slopes of Guizhou, Sichuan and Yunnan in China (Chen and Renvoize, 2006).

Given such a wide native distribution, it is not surprising that Miscanthus has also become naturalized following human introduction in many regions of the world including Eurasia, North and South America, and New Zealand (Meyer et al., 2010; Quinn et al., 2010, 2011, 2012; Barney et al., 2012; Matlaga et al., 2012; Clark et al., 2014). Clark et al. (2014) used high-density single-nucleotide polymorphism (SNP) markers to show that naturalized populations of $M$. sinensis were derived from a subset of ornamental cultivars that were themselves derived from Southern Japan.

\section{Chromosome variation}

The chromosomes of Miscanthus s.s. are relatively small, generally $25 \mu \mathrm{m}$ in metaphase of mitosis (Adati, 1958; Burner, 1991; Linde-Laursen, 1993; Hodkinson et al., 2001; Chramiec-Głąbik et al., 2012), compared with those of some grasses, but are not unusual in Panicoideae (Celarier and Paliwal, 1957; Sede et al., 2010). Early studies on $M$. floridulus and $M$. sinensis failed to reach a consensus on the basic (monoploid) chromosome number of the genus (Avdulov, 1928, 1931; Church, 1929; Hunter, 1930). However, subsequent meiotic and mitotic counts of $M$. floridulus, $M . \times$ giganteus, $M$. intermedius, M. oligostachyus, M. sacchariflorus, M. sinensis and M. tinctorius (Table 2 and Fig. 3) established the basic number at $x=19$ (Bremer, 1934; Li et al., 1948; Li and Ma, 1951; Adati and Mitsuishi, 1956; Adati, 1958). Regular meiotic behaviour with 19 bivalents has been observed in all Miscanthus s.s. with $2 n=38$ chromosomes. Further evidence for $x=19$ comes from the examination of chromosome numbers in polyploids, ranging from diploids to hexaploids (Table 2) that are represented by multiples of 19 (Adati and Shiotani, 1962). Karyotypes have been described by Adati (1958) for $M$. floridulus, M. intermedius, M. oligostachyus, $M$. sacchariflorus, $M$. sinensis and $M$. tinctorius, by Lafferty and Lelley (1994) for M. × giganteus, and by Chramiec-Głąbik et al. (2012) for M. × giganteus, M. sacchariflorus and M. sinensis.

Adati and Shiotani (1962) proposed that the $x=19$ basic chromosome number of Miscanthus is of allopolyploid origin from two parental lineages with $x=10$ and $x=9$, but this hypothesis remains to be rigorously tested. Recent mapping studies have shown a high similarity of the Miscanthus genome to the Sorghum genome and indicated whole-genome duplication in Miscanthus relative to Sorghum (Kim et al., 2012; Ma et al., 2012; Swaminathan et al., 2012). Ma et al. (2012) used genotyping by sequencing (GBS) of diploid $x=19$ M. sinensis to demonstrate that Miscanthus is an ancient polyploid relative to Sorghum bicolor consisting of two subgenomes. Each pair of the 19 M. sinensis linkages aligned to one sorghum chromosome, except one that mapped to two sorghum chromosomes. Swaminathan et al. (2012) used RNA sequencing (RNA-Seq)-based markers to also determine 19 linkage groups and showed the genome-wide duplication in Miscanthus relative to Sorghum with subsequent insertional fusion of a pair of chromosomes. Whether this ancient duplication in the Miscanthus genome involved allopolyploidy or autopolyploidy remains to be determined (Ma et al., 2012; Swaminathan et al., 2010, 2012).

The basic chromosome number of 19 in Miscanthus s.s. does not correspond to some other Miscanthus (sensu Clayton and Renvoize, 1986) species including Asian $M$. fuscus, $M$. nepalensis and $M$. nudipes and African M. ecklonii, M. junceus, M. sorghum and $M$. violaceus that generally have a basic chromosome number of 10 or 15 (Table 2; footnote). These taxa are better treated in genera separate from Miscanthus (Hodkinson et al., 2002a; as described above).

\section{Genome size variation}

Genome size has been studied by flow cytometry in Miscanthus and found to exhibit considerable variation among species (Table S1, available online). Rayburn 

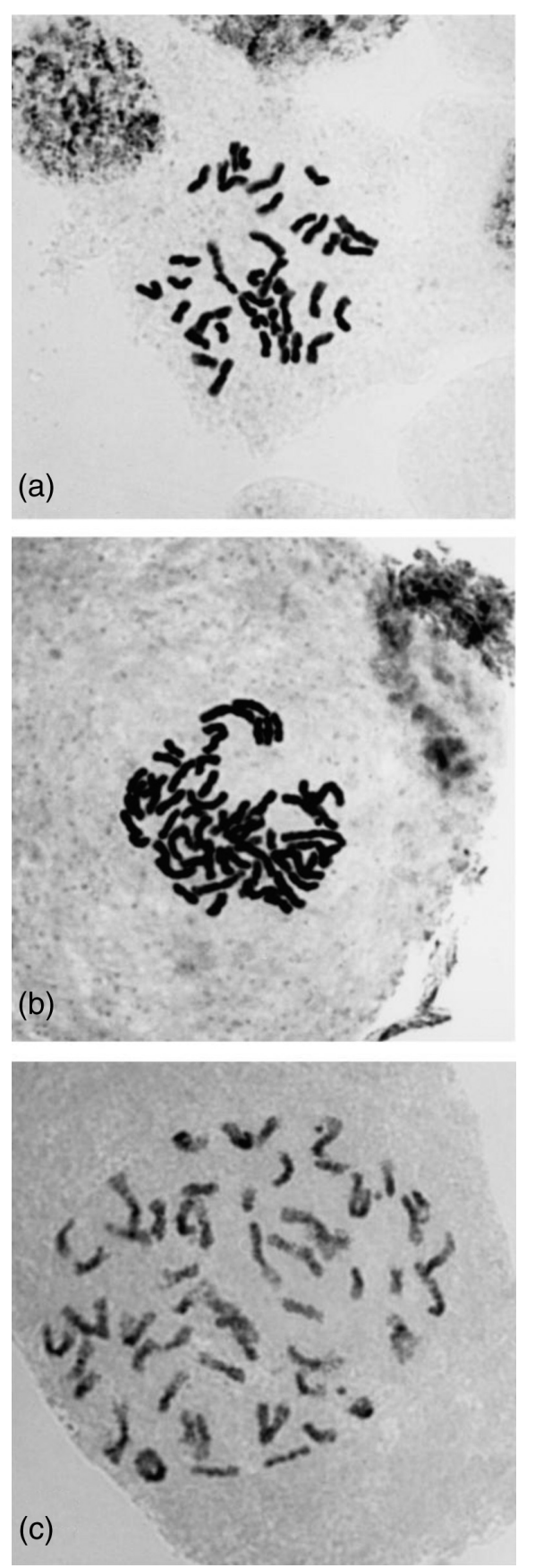

Fig. 3. Chromosomes of Miscanthus in metaphase of mitosis (from Hodkinson et al. (2001), with permission). (a, b) M. floridulus $(2 n=2 x=38)$, (c) M. $\times$ giganteus $(2 n=3 x=57)$.

et al. (2009), using three accessions of each species, showed that diploid $M$. sinensis had a 1C nuclear DNA content of $2.75 \mathrm{pg}$ and diploid $M$. sacchariflorus $2.25 \mathrm{pg}$. Therefore, they estimated the genome size of diploid $M$. sinensis to be approximately $20 \%$ greater than that of diploid M. sacchariflorus.
Li et al. (2013) examined nuclear DNA content variation in M. lutarioriparius, M. sacchariflorus and M. sinensis collected from a range of habitats, altitudes and latitudes in China. They found little variation among the species at the diploid level, suggesting that genome size was stable within the species (among populations). However, in accordance with the results reported by Rayburn et al. (2009) and De Cesare (2012), their results indicated a large difference among diploid species $(1 \mathrm{C}=2.69 \mathrm{pg}$ in M. sinensis compared with $2.19 \mathrm{pg}$ in M. sacchariflorus and M. lutarioriparius). Li et al. (2013) also estimated the genome sizes of tetraploid accessions of M. sacchariflorus and $M$. lutarioriparius and found that they had smaller genomes than expected when compared with the genome sizes of their diploid progenitors $(1 \mathrm{C}=4.27 \mathrm{pg}$ and $4.28 \mathrm{pg}$ compared with the expected value of $4.37 \mathrm{pg}$ ). This could indicate genome downsizing after polyploidization (Leitch et al., 2008; Bento et al., 2011).

Li et al. (2013) did not include M. $\times$ giganteus in their studies, but Rayburn et al. (2009) showed that triploid $M . \times$ giganteus had a total nuclear content of $7.0 \mathrm{pg}$, diploid $M$. sacchariflorus had a $1 \mathrm{C}$ content of $2.25 \mathrm{pg}$ and diploid M. sinensis had a 1C content of 2.75 pg (Table S1, available online). Rayburn et al. (2009) therefore, by simple deduction from predicted genome sizes, provided evidence that $M . \times$ giganteus is more likely the result of a combination of a $2 \times M$. sacchariflorus gamete and a $1 \times M$. sinensis gamete (sum $4.5+2.75=7.25 \mathrm{pg})$ than that of a $2 \times M$. sinensis gamete and a $1 \times$ M. sacchariflorus gamete $(5.5+2.25=7.75 \mathrm{pg})$.

From these values, it is possible to estimate genome size in base pairs (bp) for the following three species: M. × giganteus, M. sacchariflorus and $M$. sinensis (diploids to tetraploids; higher-ploidy plants excluded). The genomes (Table S1, available online), ranging in estimated size from $2.1 \mathrm{Gbp}$ (diploids) to $5.62 \mathrm{Gbp}$ (tetraploids), are large in comparison with those of Arabidopsis (125 Mbp), similar in size to those of maize (2.3 Gbp), small in comparison with those of bread wheat (17 Gbp) and tiny in comparison with the largest genome measured thus far, Paris japonica (Pellicer et al., 2010), of $150 \mathrm{Gbp}$.

Swaminathan et al. (2010) used genomic and small RNA-Seq to characterize the genome of $M . \times$ giganteus. Coding regions were found to show a high sequence similarity to those in other grasses, but $95 \%$ of the genome was found to fall within 12 repeat classes of DNA related to transposons or centromeric DNA. The major repeats actively produce small RNAs. Most small RNAs (sRNAs) in grasses are in the 24-nucleotide size range (probably small interfering RNA (siRNAs)). Retrotransposons (class 1 transposons) are the most common sRNA (32\%), followed by DNA transposons (class 2 transposons). Thus, siRNAs were suggested to represent 
a large component of the small-RNA transcriptome of Miscanthus (Swaminathan et al., 2010).

\section{Polyploidy}

Ploidy estimation in Miscanthus has been achieved by flow cytometry and counting techniques (Table 2). Miscanthus is a polyploid complex with diploids, triploids, tetraploids, pentaploids and hexaploids. Hodkinson et al. (2002c) used amplified fragment length polymorphism (AFLP) fingerprinting in combination with chromosome counting to show that many plants labelled as $M$. sacchariflorus are in fact $M . \times$ giganteus. Morphologically these taxa are hard to separate even with flowering specimens (Hodkinson and Renvoize, 2001; Hodkinson et al., 2002a), and a combination of methods including ploidy determination is often required to correctly assign a name to specimens. Many of the $M$. sacchariflorus polyploids have been assigned infraspecific status including $M$. sacchariflorus var. brevibarbis (triploid), M. sacchariflorus var. glaber (triploid), M. ogiformis (triploid) and M. sacchariflorus f. latifolius (pentaploid).

Evidence for autopolyploidy has been provided for some genotypes or taxa including autotriploid M. sinensis 'Goliath' (De Cesare, 2012), autotriploid M. sinensis var. condensatus (Adati and Mitsuishi, 1956; Adati, 1958), M. sinensis 'Autumn Light' (Swaminathan et al., 2010), autotetraploid M. sacchariflorus (Adati and Mitsuishi, 1956; Adati, 1958) and autotriploid M. sacchariflorus. However, it is possible that some of these taxa are the result of hybridization and hence allopolyploidy.

Evidence for allopolyploidy has been provided for several Miscanthus taxa (Adati and Shiotani, 1962), but most notably for M. $\times$ giganteus (Linde-Laursen, 1993; Hodkinson et al., 2002b; Nishiwaki et al., 2011) and some taxa in the $M$. sacchariflorus complex including allotriploid $M$. sacchariflorus var. brevibarbis and M. sacchariflorus var. glaber (Adati and Shiotani, 1962). Adati and Shiotani (1962) used karyotype analysis and observations of chromosome pairing in meiosis to show that some tetraploid $M$. sacchariflorus are of allopolyploid origin. These tetraploids were composed of two different chromosomal sets, one with a satellite chromosome and another without a satellite chromosome. Two sets are homologous to $M$. sinensis and two partially homologous. They also argued, on the basis of meiotic and morphological studies, that pentaploid M. sacchariflorus var. latifolius is an allopolyploid combining genomes of $M$. sacchariflorus and $M$. sinensis and that $M$. intermedius is an allopolyploid combining genomes of $M$. oligostachyus and M. tinctorius.

\section{Origin of Miscanthus giganteus and polyploid M. sacchariflorus taxa}

The allopolyploid origin of $M . \times$ giganteus has been established via morphological, geographical, cytogenetic, molecular genetic and pollen fertility/seed viability studies. Linde-Laursen (1993) examined meiotic pairing in $M . \times$ giganteus and found few trivalents and nearly equal numbers of bivalents and univalents, which indicates that two of the three genomes have high homology and one has low homology to the other two. All pollen grains were sterile with two to five apertures (compared with single-aperture grains in fertile Miscanthus). Meiotic pairing in $M . \times$ giganteus contrasts with that in autotriploid M. sinensis ssp. condensatus, which was shown to have a high number of trivalents in pollen mother cells at metaphase 1 (Adati, 1958).

Hodkinson et al. (2002b) used nuclear ribosomal DNA sequences from the internal transcribed spacer (ITS) region to show that both $M$. sinensis and $M$. sacchariflorus were the parental genome donors of $M . \times$ giganteus. One ITS repeat type in $M . \times$ giganteus matched $M$. sinensis and the other $M$. sacchariflorus (Fig. 4). AFLP and inter-simple-sequence repeat (ISSR) fingerprinting also confirmed this observation. The molecular cytogenetic techniques such as fluorescent in situ hybridization and genomic in situ hybridization were unable to differentiate among the different parental genomes present in $M . \times$ giganteus, indicating that the parental genomes of the triploid are extremely similar at the repetitive DNA level.

Plants classified as M. sacchariflorus also have complex ancestry and are difficult to classify and name because chromosome complements range from diploid to pentaploid (Adati, 1958; Adati and Shiotani, 1962; Fedorov, 1969). Miscanthus sinensis and M. sacchariflorus hybridize and introgression is expected among these taxa to produce monoploid and polyploid taxa (Adati and Shiotani, 1962). The morphological characteristics that differentiate the two species, such as the absence/presence of an awn, length of the callus hairs and culm buds, are insufficient to separate interspecific hybrids. More work is required to fully understand the M. sacchariflorus ploidy complex (Lledó et al., 2001).

Plastid genome variation has been studied in Miscanthus using gene sequencing (Hodkinson et al., 2002a, b; Feng et al., 2014) and microsatellite markers (De Cesare et al., 2010; De Cesare, 2012; Głowacka et al., 2014a, b). Different, and species-specific, plastid haplotypes were detected by Hodkinson et al. (2002a,b) and De Cesare (2012), and these were used to assess the maternal origin of $M . \times$ giganteus and also the phylogeny of Miscanthus species in combination with nuclear ribosomal DNA. Plastid DNA is generally 


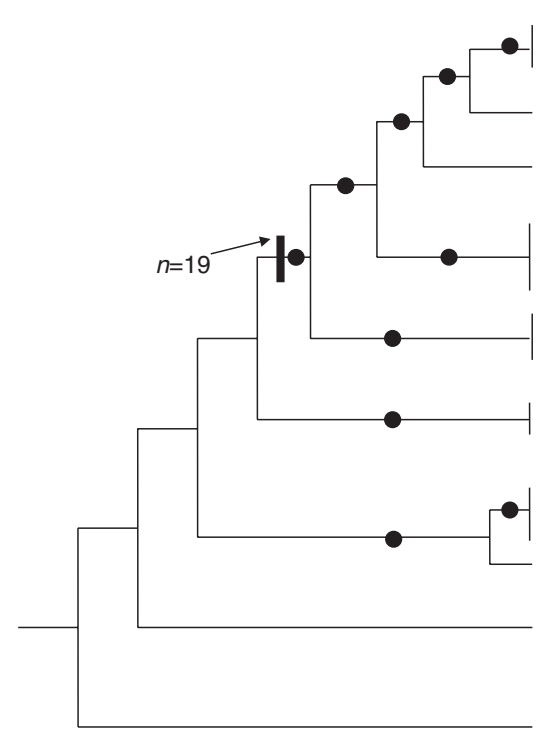

Miscanthus sinensis

M. $\times$ giganteus $\odot$

M. floridulus

M. transmorrisonensis

M. $\times$ giganteus $\odot$

M. sacchariflorus $\odot$

M. lutarioriparius

M. oligostachyus

M. tinctorius, $M$. intermedius

Saccharum spontaneum

S. officinarum

M. ecklonii, M. junceus

M. sorghum, M. violaceus

M. fuscus (Sclerostachya)

M. nepalensis (=Diandranthus)

Saccharum complex (other genera)

Fig. 4. Summary of phylogenetic relationships in Miscanthus and related taxa based on nuclear ribosomal sequences (adapted from Hodkinson et al. (2002a, b, c) and Swaminathan et al. (2010)). ๑, Note M. sacchariflorus and M. × giganteus accessions share plastid haplotypes, indicating that $M$. sacchariflorus is the ovule donor and $M$. sinensis the pollen donor of all M.× giganteus hybrids studied thus far by the current authors. $\bullet$, well-supported clades.

maternally inherited in grasses, and $M . \times$ giganteus was shown to have the plastid type of $M$. sacchariflorus in all samples studied. Therefore, the allotriploid M. $\times$ giganteus inherited its plastid (and by extrapolation mitochondrial DNA) from a M. sacchariflorus lineage (Fig. 4).

Some artificial crosses of $M$. sinensis and M. sacchariflorus were included in the study carried out by De Cesare (2012). In several of these, the hybrid had the plastid genome of $M$. sinensis, showing that hybridization is possible in both directions (with both species as maternal parent). This is supported by Clark et al. (2014), who determined, in a major SNP study, many US ornamentals labelled as $M$. sinensis to be in fact BC1 or BC2 hybrids of $M$. sacchariflorus and M. oligostachyus with $M$. sinensis as the recurrent female parent. There is no reason to believe that the formation of $M . \times$ giganteus in the wild is unidirectional, but the plastid studies carried out by Hodkinson et al. (2002a) and De Cesare (2012) suggest that this could be nearly the case as all putatively wild sourced $M . \times$ giganteus accessions have M. sacchariflorus plastid DNA. Clark et al. (2014) found the M. sacchariflorus plastome in nine of the 11 Chinese interspecific sacchariflorus $\times$ sinensis hybrids collected from the wild. Triploid seeds have also been found on M. sacchariflorus inflorescences in a sympatric zone with $M$. sinensis in Japan (Nishiwaki et al., 2011). Unidirectional hybridization can be caused by several factors including nuclear cytoplasmic DNA incompatibility effects (Anderson and Maan, 1995) or by population factors. For example, if $M$. sinensis was rare and M. sacchariflorus common (or if phenological differences created such a pattern), the vast number of seeds set would be from $M$. sacchariflorus ovule donors. However, a small number of $M$. sinensis plants can potentially father a large number of $M . \times$ giganteus seeds.

Nishiwaki et al. (2011) investigated natural occurrences of triploidy in sympatric populations of tetraploid M. sacchariflorus and diploid M. sinensis in Japan. The interspecific hybrid, now known as Miscanthus $\times$ giganteus, was first collected in Yokohama, Japan, by a Danish plant collector (Nielsen, 1990) and subsequently introduced around the world. Japan is therefore a likely source of new natural allotriploid $M . \times$ giganteus. Nishiwaki et al. (2011) measured seed set of sympatric $M$. sinensis and $M$. sacchariflorus and assessed their DNA content with flow cytometry. Triploid seeds were found on the inflorescences of $M$. sacchariflorus. These plants have great potential as new sources of variation in breeding programmes. However, they originate from the warm moist regions of Southern Japan. The authors speculate that more cold-tolerant $M . \times$ giganteus would be expected from more northerly and cooler regions of Japan (Nishiwaki et al., 2011).

\section{Aneuploids and B chromosomes}

Linde-Laursen (1993) reported a hyperploid chromosome number of 58 in $M . \times$ giganteus (trisomic). Aneuploidy 
has not otherwise been confirmed in many other cytological studies. However, the occurrence of accessory (B) chromosomes has been reported in some but not all Miscanthus species (Li and Ma, 1951; Price, 1963a, b; Linde-Laursen, 1993). Price (1963a) recorded between 0 and $11 \mathrm{~B}$ chromosomes in six clones of M. floridulus, and Linde-Laursen (1993) reported between 0 and 4 B chromosomes approximately $0.7 \mu \mathrm{m}$ in length in two clones of M. $\times$ giganteus. Chramiec-Głąbik et al. (2012) reported one to four B chromosomes in $M . \times$ giganteus, two in M. sinensis and four in M. sacchariflorus.

\section{Artificial polyploids and haploids}

Chromosome doubling has been used to generate artificial polyploids in Miscanthus and has potential to introduce new genetic diversity into breeding programmes especially for $M$. $\times$ giganteus types by manipulating the ploidy of the parental species, restoring fertility or disrupting the self-incompatibility system (Petersen et al., 2002; Głowacka et al., 2009, 2010a, b; Yu et al., 2009). Another stimulus for artificial polyploid formation has been the desire to generate novel sterile genotypes that lower the risk of invasiveness following introduction as a crop (Petersen et al., 2003; Barney and Ditomaso 2008; Jørgensen, 2011). Petersen et al. (2002, 2003) generated tetraploid $M$. sinensis from diploid source plants using colchicine or oryzalin treatments during callus induction, during callus proliferation, or on in vitro shoot apices and leaf explants. These tetraploids can be used as parental species in triploid Miscanthus production with $M$. sacchariflorus. Treatment of shoot apices with colchicine was shown to be the most efficient method for the four genotypes tested.

Triploid $M . \times$ giganteus is sterile in a post-zygotic barrier that results from abnormal male and female gametophyte production (Słomka et al., 2012). Hexaploid $M . \times$ giganteus has been generated from triploid source material in an attempt to restore its fertility. For example, Yu et al. (2009) treated triploid callus, obtained from immature panicles, with colchicine and oryzalin to generate hexaploids. These were also found to have an increased stomata size $(30 \mu \mathrm{m}$ in the hexaploids compared with $24.3 \mu \mathrm{m}$ in the triploids), but they did not report any findings for the fertility of the hexaploids. Touchell and Ranney (2012) also used oryzalin for in vitro chromosome doubling of $M . \times$ giganteus. Fertility of the resulting hexaploids was shown using pollen viability staining and crossing of the hexaploids with diploid M. sinensis, but in vitro embryo culture was required to obtain viable plantlets.

Haploid plants and double-haploid plants have also been reported (Głowacka et al., 2009; Głowacka et al., 2012) and used in the gene expression studies of Miscanthus (Barling et al., 2013). Głowacka et al. (2012) developed a methodology for haploid formation by anther culture in M. sinensis. Androgenesis has also been attempted in M. $\times$ giganteus (Zur et al., 2013), but its efficiency is very low due to cytological chromosome imbalance.

\section{Genotyping: genetic variation and phylogeography}

Several multi-locus marker systems have been applied to Miscanthus such as restriction fragment length polymorphism (RFLP; Hernández et al., 2001), randomly amplified polymorphic DNA (RAPD; Chiang et al., 2003), ISSR polymerase chain reaction (ISSR-PCR; Hodkinson et al., 2002c; Zhang et al., 2013a, b) and AFLP (Greef et al., 1997; Hodkinson et al., 2002c). Single-locus co-dominant markers have also been applied including isozymes (Chou et al., 1987; Chou and Chang, 1988; Chou and Ueng, 1992; Von Wühlisch et al., 1994). Many simple-sequence repeat (SSR) markers have been developed for the nuclear genome (Hernández et al., 2001; Hung et al., 2009; Ho et al., 2011; Zhou et al., 2011; Hu et al., 2012; Kim et al., 2012; Yu et al., 2013), but fewer have been developed for the plastid/chloroplast genome (De Cesare et al., 2010; Jiang et al., 2012). Recently, comprehensive SNP surveys have been conducted using next-generation sequencing approaches (Slavov et al., 2014; Clark et al., 2014; Głowacka et al., 2014a, b). A more detailed history of molecular marker development has been given elsewhere (Głowacka, 2011; Ma et al., 2012; Hodkinson et al., 2013).

Studies have demonstrated considerable genetic diversity in breeding collections and wild populations of Miscanthus at the infraspecific level (Greef et al., 1997; Hodkinson et al., 2002c; Głowacka et al., 2014a, b). Greef et al. (1997) and Hodkinson et al. (2002c) showed that AFLP markers could easily differentiate cultivars and infraspecific taxa of Miscanthus. However, they detected very little variation among the accessions of $M . \times$ giganteus collections and used the markers to help identify clonal material.

Diversity in $M . \times$ giganteus collections is a major cause for concern. Głowacka et al. (2014a, b) used nuclear and chloroplast SSRs in combination with restriction siteassociated DNA sequencing to estimate genetic similarity in over $30 \mathrm{M} . \times$ giganteus accessions of unknown provenance (legacy cultivars) from collections in North America and Europe and some newly bred $M . \times$ giganteus genotypes grown from seed and found that genetic variation in the legacy cultivars was extremely low. A total of 27 of these legacy cultivars were inferred as clones matching the M.× giganteus type specimen. 


\section{Population genetics and genetic diversity}

Population genetic and adaptive variation data are required to determine gene pools for Miscanthus breeding and to understand physiological adaptations to abiotic stress such as temperature, drought and salinity. These limiting factors are crucial obstacles to overcome for developing crops that are suitable for growth in a wide range of climates and environments including marginal land (Jones et al., 2014). Population genetic information is also important to develop knowledge about the evolution of Miscanthus and the impact of past and future climate on its distribution (Hodkinson (2011); De Souza et al., 2013; Clark et al., 2014).

Several studies have been carried out on genetic variation in Miscanthus, especially in M. sinensis, and the geographical centres of diversity including China, Korea and Japan. For example, Slavov et al. (2014) used SNP and SSR markers to study putatively neutral geneticdiversity in a large breeding collection of Miscanthus. They also included 17 phenotypic traits related to biomass, phenology, cell-wall composition and morphology. They used the resulting data to delineate a reduced population of $145 \mathrm{M}$. sinensis genotypes to be used for association mapping and GS. Their data revealed considerable population genetic differentiation/structure in M. sinensis over the geographical space from Korea to Japan with a longitudinal cline (from $124^{\circ}$ to $142^{\circ}$ E) accounting for a high proportion of the molecular variation. In contrast, they found that latitude and altitudinal variation best explained variation in the phenotypic traits.

A genetic diversity study was conducted by Zhao et al. (2013a, b) in over 450 M. sinensis accessions collected from a representative range across China using 23 SSR markers. High genetic diversity was detected and clustering of individuals was consistent with geographical distribution. However, within-subpopulation variation was substantially greater (83\%) than among-subpopulation variation (17\%), which is not unusual given the outbreeding and perennial nature of the species. Miscanthus sinensis also has good dispersal ability via its light feathery spikelets (Fig. 1) that facilitate gene flow.

Mating system has also been shown to contribute to patterns of population diversity and differentiation using RAPD markers and DNA sequence variation in outcrossing M. sinensis (from Japan, China and Taiwan) and inbreeding $M$. condensatus from Taiwan (Chou et al., 2000; Chiang et al., 2003). Chiang et al. (2003) studied sequence variation at the nuclear ADH1 locus and plastid trnL-F spacer regions. Low levels of genetic diversity were detected in $M$. condensatus that could be explained by bottlenecks caused by selfing in all populations. The ADH1 locus was under positive selection in lineages of M. condensatus that could be explained by pressure to evolve in response to different ecological conditions in saline habitats in which it is distributed (Chiang et al., 2003).

A recent study carried out by Clark et al. (2014) examined a sample of over $600 \mathrm{M}$. sinensis accessions covering a large proportion of its native range in China, South Korea and Japan using a high-density set of SNP markers and ten plastid microsatellites. The markers detected six genetic clusters from geographically distinct regions. Four clusters were from mainland Asia (Southeast China, Yangtze-Qinling, Sichuan Basin and Korea/ North China) and two were from Japan (Southern and Northern). They also included some $M$. floridulus in their analyses and found them to cluster with $M$. sinensis, demonstrating their close relationship and questioning their species status. All plastid haplotypes observed in M. floridulus were also common in M. sinensis. This was consistent with the results of the study carried out by Hodkinson et al. (2002a) in which M. floridulus accessions were found to be embedded in a $M$. sinensis clade and with morphological intergradation of these species (Scally et al., 2001a, b). Only four M. floridulus accessions were included in the study carried out by Clark et al. (2014), and further studies are required to confirm these early observations.

Clark et al. (2014) also provided evidence that Southeast China was the centre of origin for the M. sinensis accessions found in temperate Eastern Asia. Their data were consistent with the hypothesis that Southeast China acted as a refugium during the last glacial maximum. They did not include other more southerly populations of M. sinensis, so it is not clear how important this refugium was in comparison with others that could have existed in former Indo-China, the Philippines, Indonesia and the South Pacific.

Genetic structure has also been detected on finer geographical scales. For example, Iwata et al. (2004) used AFLP fingerprinting and PCR-RFLP to detect three regional subgroups of $M$. sinensis ssp. condensatus in Miyake Island, Japan. They also detected a rare haplotype most probably transmitted from outside the island. Shimono et al. (2013) investigated variation in Miscanthus sinensis in Japan using chloroplast DNA and detected nine haplotypes from over 600 individuals sampled from 30 populations. Two putative ancestral lineages were detected in the Ryukyu Islands, suggesting that they might have migrated from China via Taiwan or possibly the Korean Peninsula.

\section{Adaptive variation}

Field trials and laboratory-based controlled experiments, using a broad range of genotypes, have revealed variation 
in agronomic traits such as yield (Jeżowski et al., 2011; Gauder et al., 2012), drought tolerance (Clifton-Brown and Lewandowski, 2002), temperature control of leaf growth (Farrell et al., 2006), frost and cold tolerance (Clifton-Brown and Jones, 1997; Weng and Ueng 1997; Zub et al., 2012; Głowacka et al., 2014a, b), flowering time (Clifton-Brown et al., 2008; Jensen, 2009; Jensen et al., 2011; Zhang et al., 2012), senescence (Robson et al., 2011), chemical composition and morphology (Jørgensen, 1997; Kaack et al., 2003; Hodgson et al., 2010, 2011; Allison et al., 2011; Zhao et al., 2013a, b, 2014), and seed germination (Dwiyanti et al., 2014). These studies have demonstrated huge phenotypic variation in and among Miscanthus species (Zub and Brancourt-Hulmel, 2010; Jones et al., 2014) that can be utilized in breeding.

Other researchers have set up common garden experiments with different genotypes grown at multiple locations to provide insights into the natural levels of adaptive variation (Clifton-Brown et al., 1999; CliftonBrown and Lewandowski, 2000; Yan et al., 2012). Clifton-Brown and Lewandowski (2000) used field trials to examine the overwintering success of newly established Miscanthus genotypes from different sources in Asia. They planted these at four sites across a temperature gradient in Europe (Sweden, Denmark, Germany and England) and found considerable variation among the limited number of genotypes that they tested. Yan et al. (2012) also used common garden experiments, but for a much larger sample of Miscanthus (93 genotypes) collected across their natural geographical range in China. They grew these in three locations representing temperate grassland with cold winter, semi-arid Loess Plateau and relatively warm and wet Central China and detected high variation in growth traits and significant levels of site $\times$ population interactions for most traits. Genotypes with high levels of plasticity that can produce good yields, in a broad range of habitats, were identified. These physiological experiments, field trials and common garden studies are helping to delineate populations of Miscanthus genotypes suitable for association mapping and GS (Slavov et al., 2014).

\section{Linking genotype to phenotype}

Some recent studies have used gene expression analysis to understand phenotypic variation in Miscanthus using methods such as RNA-Seq. Chouvarine et al. (2012) used transcriptome sequencing of rhizome samples to generate an exome sequence database for Miscanthus complete with gene ontology functional annotations. Their data were used to differentiate closely related Miscanthus cultivars. Barling et al. (2013) also generated a comprehensive expressed sequence tag (EST) catalogue using RNA-Seq that was predicted to represent a high proportion of the Miscanthus transcriptome using comparisons with sorghum gene models. They compared gene expression profiles in different tissues and a range of developmental stages. They also analysed expression profiles in rhizomes characterized in the spring compared with those characterized in the autumn to reveal biological pathways that exhibit altered regulation. Some candidate gene work has also been undertaken to understand variation in important lignin-related genes. For example, Suman et al. (2011) studied variation in caffeic acid O-methyltransferase (COMT), cinnamyl alcohol dehydrogenase $(C A D)$, cinnamoyl-CoA reductase $(C C R)$ and ferulate 5-hydroxylase $(F 5 H)$ genes with target region amplification polymorphism markers and detected sufficient variation to distinguish species of the Saccharum complex. However, they did not include sufficient numbers of genotypes to assess variation within and among the Miscanthus species.

Another study has focused on generating genetic linkage maps of Miscanthus that are needed for several applications such as quantitative trait locus (QTL) analysis and marker-assisted selection (MAS). High-resolution maps based on sequence markers allow the use of QTLs accessible from other grass species through alignment based on syntenic relationships (Ma et al., 2012). However, such maps have been produced only recently.

\section{Mapping}

Some studies have used markers for genetic mapping, but progress has been slow because of the large and heterozygous genome of Miscanthus. Mapping projects have therefore focused on diploid $M$. sinensis to facilitate genetic inheritance studies. The first published linkage map for Miscanthus (Atienza et al., 2002) was a breakthrough in the field. This map was generated using 257 PCR fingerprinting markers (RAPD) for offspring cross-mapping using an outbred population of $89 \mathrm{M}$. sinensis individuals (both parents full sibs). The markers were spread over 28 linkage fragments that spanned a total map length of $1074.5 \mathrm{cM}$ with an average density of $4.2 \mathrm{cM}$ per marker (but half of the fragments contained only two to four markers). Maps based on non-sequence-based markers (RAPD, AFLP and diversity array technology markers) do not provide alignable information for cross-utilization studies (Zhang et al., 2013a, b).

Higher-resolution genetic maps of Miscanthus species based on DNA sequence markers have recently been generated using next-generation sequencing technology (Ma et al., 2012; Swaninathan et al., 2012). This has allowed for data transferability and several comparative genomic analyses. The map of $M$. sinensis developed 
by Swaminathan et al. (2012) was based on a full-sib (F1) population produced by reciprocally crossing two ornamental clonally propagated $M$. sinensis accessions (Grosse Fontaine $\times$ Undine). Their analysis, including 868 segregating SNP and SSR markers, detected 19 linkage groups (consistent with the basic chromosome number $x=19)$. The total length on the new max likelihood map was $1782 \mathrm{cM}$ (estimated total length of $1884 \mathrm{cM}$ accounting for telomeric ends). In an integrated map of Grosse Fontaine and Undine, 97\% of the mapped markers lie within $10 \mathrm{cM}$ of another marker.

In the same year, Ma et al. (2012) used an alternative sequencing approach known as GBS to identify the 19 linkage groups and produced a higher-resolution genetic map. It was based on an outcrossing full-sib F1 mapping population (called $M \times 2$ ). Their composite linkage map combining markers from both parental linkage maps included 3745 SNP markers spanning $2396 \mathrm{cM}$ with an average resolution of $0.64 \mathrm{cM}$. The mapping population of Ma et al. (2012) segregates for important agronomic traits such as flowering time, biomass yield, stem number, senescence and spring emergence and can be applied for QTL studies and MAS.

\section{QTLS}

Despite their comparatively low resolution, the early maps (Atienza et al., 2002) were applied to QTL analysis of agronomic and combustion traits (Atienza et al., 2003a, b, c, d). Atienza et al. (2003a) used their genetic map (Atienza et al., 2002) to localize QTLs in M. sinensis controlling total height, flag leaf height and basal culm diameter. Field data were collected over two years to investigate developmental and environmental effects. Of the potential 11 reported QTLs, three were considered to be significant including total height, basal culm diameter and flag leaf height. Atienza et al. (2003b) almost simultaneously published a paper using a similar methodology to investigate QTLs of yield components in M. sinensis. They detected 20 potential QTLs: six associated with yield, eight with stem yield, two with leaf yield and four with top yield. Atienza et al. (2003c, d) also applied the same mapping population and RAPD markers to investigate QTLs influencing combustion quality traits. Atienza et al. (2003c) detected nine putative QTLs: two for calcium, two for sulphur and five for phosphorus, and Atienza et al. (2003d) detected four for chlorine and two for potassium.

These studies represent significant first steps in QTL detection, but it is not known how stable they are over time (years of trial and age of the plants) and how much they are influenced by the environment (Atienza et al., 2003d). We are currently in a period of considerable progress in QTL mapping in Miscanthus with the application of high-density/resolution genetic maps (Armstead et al., 2009). Because of the advances in DNA sequencing technology, it is likely that the limiting step will be high-quality phenotyping (Myles et al., 2009).

MAS programmes in Miscanthus are underway at several institutions, for example, the University of Illinois, USA, on traits such as yield, stability, flowering time, overwintering ability, low-temperature photosynthesis, leaf extension and drought tolerance (Sacks, pers. commun.). An introgression programme of Saccharum into Miscanthus is ongoing at the same research institute (http://www.energybiosciencesinstitute.org/directory/ sacks-erik). Furthermore, a significant MAS Miscanthus breeding programme is being carried out at the Institute of Biological, Environmental and Rural Sciences (IBERS), Wales (http://www.aber.ac.uk/en/ibers/). MAS for salt tolerance is being investigated at Wageningen University, the Netherlands (http://edepot.wur.nl/155120).

\section{Association mapping and GS}

Association mapping (linkage disequilibrium (LD) mapping) is a method of mapping QTLs that takes advantage of historical LD to link phenotypes to genotypes (Myles et al., 2009). The genome is sampled for markers (such as SNPs) and associations are statistically detected between markers and a particular phenotype. Associations are independently verified to show that they (1) directly contribute to the trait of interest or (2) are linked to (in LD with) a QTL that contributes to the trait of interest. For example, Zhao et al. (2013a, b) found nine SSRs associated with heading date and biomass yield in $M$. sinensis using association analysis between measured traits and 115 SSR marker alleles.

Association mapping in the form of a genome-wide association study (GWAS) is an advance on standard association mapping and has been most widely applied to the study of human diseases and cattle breeding and more recently to plants including Miscanthus (Slavov et al., 2014). Slavov et al. (2014) used GWAS to study 17 traits related to phenology, biomass and cell-wall composition using a sample of 138 Miscanthus sinensis genotypes and over 100,000 single-nucleotide variants.

In crops, GS has successfully been implemented first in model crop species such as rice and maize. In rice, GS has been carried out for eight traits (yield, tiller number, grain number, 1000-grain weight, grain length, grain width, heading date and apicule colour; Xu, 2013). In maize, GS for kernel spacing has been reported (Crossa et al., 2013). It remains to be seen whether the 
high-density marker association approaches can prove suitable for GS in Miscanthus for advances in biomassrelated traits such as stem diameter, stem-to-leaf ratio, cell-wall composition, or improved hardiness under adverse climatic or soil conditions.

\section{Comparative genomics}

Currently, there are few genomic resources available to Miscanthus breeders, except for some genomic and EST data (Kim et al., 2014), compared with rich QTL knowledge and physical data aligned with a high-quality reference genome of Sorghum (Zhang et al., 2013a, b). However, the genomic resources available to breeders are likely to increase enormously over the next decade and will be utilized together with the resources of other well-characterized grass species such as sorghum, wheat, rice and maize. These resources of other Saccharinae and Sorghinae will prove particularly useful. Comparative genomic resources such as the CSGRqtl database (http://helos.pgml.uga.edu/qtl/) will facilitate the cross-utilization of information among Saccharinae taxa and complement Gramene (http:// www.gramene.org), which includes mapping data from a broad diversity of grass taxa. The CSGRqtl database uses sorghum genome sequence as its central reference. It helps facilitate QTL mapping and characterize the function of genes that underlie QTLs. It can facilitate the investigation of genetic control of traits across genomes of divergent taxa and paleoduplicated subgenomes, as is the case in Miscanthus. These resources will combine genome data when they become available for Miscanthus species.

\section{Conclusions}

Natural genetic diversity is high in the Miscanthus polyploid complex and much progress has already been made in the characterization, evaluation and utilization of these resources so that artificial selection is not restricted by a lack of variation. The natural genetic diversity in Miscanthus has been characterized to define gene pools and used to help direct novel crossing work, manipulate ploidy, undertake QTL and association mapping studies, and develop GS selection programmes. Miscanthus therefore serves as a model for the use of genetic resources for new crop development. Advances in genetics underlying agronomic traits and the manipulation of these characteristics in breeding programmes will depend on the efficient utilization of existing collections and also on future collections aimed at targeting a maximum natural genetic diversity. There is a need for detailed phenotyping descriptor lists, a network of genetic resource collections and better seed/field bank coordination at the international level.

\section{Supplementary material}

To view supplementary material for this article, please visit http://dx.doi.org/10.1017/S147926211400094X

\section{Acknowledgements}

This work was supported by FP7 KBBE.2011.3.1-02 grant number 289461 (GrassMargins).

\section{References}

Adati S (1958) Studies on the genus Miscanthus with special reference to the Japanese species suitable for breeding purposes as fodder crops. Bulletin of the Faculty of Agriculture Mie University 17: 1-112.

Adati S and Mitsuishi S (1956) Wild growing forage plants of the Far East, especially Japan, suitable for breeding purposes, part 1, karyological study in Miscanthus (1). Bulletin of the Faculty of Agriculture Mie University 12: 1-10.

Adati S and Shiotani I (1962) The cytotaxonomy of the genus Miscanthus and its phylogenic status. Bulletin of the Faculty of Agriculture Mie University 25: 1-24.

Allison GG, Morris C, Clifton-Brown JC, Lister SJ and Donnison IS (2011) Genotypic variation in cell wall composition in a diverse set of 244 accessions of Miscanthus. Biomass and Bioenergy 35: 4740-4747.

Anderson JA and Maan SS (1995) Interspecific nuclearcytoplasmic compatibility controlled by genes on group 1 chromosomes in durum wheat. Genome 38: 803-808.

Arabidopsis genome initiative, (2000) Analysis of the genome sequence of the flowering plant Arabidopsis thaliana. Nature 408: 796-815.

Armstead I, Huang L, Ravagnani A, Robson P and Ougham H (2009) Bioinformatics in the orphan crops. Briefings in Bioinformatics 10: 645-653.

Atienza SG, Satovic Z, Petersen KK, Dolstra O and Martín A (2002) Preliminary genetic linkage map of Miscanthus sinensis with RAPD markers. Theoretical and Applied Genetics 105: 946-952.

Atienza SG, Satovic Z, Petersen KK, Dolstra O and Martín A (2003a) Identification of QTLs influencing agronomic traits in Miscanthus sinensis Anderss. I. Total height, flagleaf height and stem diameter. Theoretical and Applied genetics 107: 123-129.

Atienza SG, Satovic Z, Petersen KK, Dolstra O and Martín A (2003b) Identification of QTLs influencing combustion quality in Miscanthus sinensis Anderss. II. Chlorine and potassium content. Theoretical and Applied Genetics 107: $857-863$.

Atienza SG, Satovic Z, Petersen KK, Dolstra O and Martín A (2003c) Identification of QTLs associated with yield and its components in Miscanthus sinensis Anderss. Euphytica 132: 353-361. 
Atienza SG, Satovic Z, Petersen KK, Dolstra O and Martín A (2003d) Influencing combustion quality in Miscanthus sinensis Anderss.: identification of QTLs for calcium, phosphorus and sulphur content. Plant Breeding 122: $141-145$.

Avdulov NP (1928) Systematic karyology of the family Gramineae. Proceedings of the All-Russian Botanists Congress. 65-97.

Avdulov NP (1931) Karyo-systematische Untersuchung der Familie Gramineen. Bulletin of Applied Botany, Genetics and Plant Breeding. Suppl. 43.

Barling A, Swaminathan K, Mitros T, James BT, Morris J, Ngamboma O, Hall MC, Kirkpatrick J, Alabady M, Spence AK, Hudson ME, Rokhsar DS and Moose SP (2013) A detailed gene expression study of the Miscanthus genus reveals changes in the transcriptome associated with the rejuvenation of spring rhizomes. BMC Genomics 14: 864, doi:10.1186/1471-2164-14-864.

Barney JN and Ditomaso JM (2008) Nonnative species and bioenergy: are we cultivating the next invader? BioScience 58 : $64-70$.

Barney JN, Mann JJ, Kyser GB and DiTomaso JM (2012) Assessing habitat susceptibility and resistance to invasion by the bioenergy crops switchgrass and Miscanthus $\times$ giganteus in California. Biomass and Bioenergy 40: $143-154$.

Bennett MD and Smith JB (1991) Nuclear DNA amounts in angiosperms. Philosophical Transactions of the Royal Society of London B 334: 309-345.

Bennett MD and Leitch IJ (2005) Nuclear DNA amounts in angiosperms: progress, problems and prospects. Annals of Botany 95: 45-90.

Bennett MD and Leitch IJ (2012) Plant DNA C-values database (release 6.0, December 2012). Available at http://data. kew.org/cvalues/

Bennett MD, Leitch IJ, Price HJ and Johnston JS (2003) Comparisons with Caenorhabditis $(\sim 100 \mathrm{Mb})$ and Drosophila $(\sim 175 \mathrm{Mb})$ using flow cytometry show genome size in Arabidopsis to be $\sim 157 \mathrm{Mb}$ and thus $25 \%$ larger than the Arabidopsis genome initiative estimate of $\sim 125 \mathrm{Mb}$. Annals of Botany 91: 547-557.

Bento M, Gustafson JP, Viegas W and Silva M (2011) Size matters in Triticeae polyploids: larger genomes have higher remodeling. Genome 54: 175-183.

Bouchenak-Khelladi Y, Salamin N, Savolainen V, Forest F, Bank M, Van Der, Chase MW and Hodkinson TR (2008) Large multi-gene phylogenetic trees of the grasses (Poaceae): progress towards complete tribal and generic level sampling. Molecular Phylogenetics and Evolution 47: 488-505.

Brett PGC (1954) Saccharum-Miscanthidium hybrids. Journal of Genetics 52: 542-546.

Bremer G (1934) De cytology van het suikerriet. VII. Een cytologisch onderzoek van een vifftigtal in 1929-1930 op Java geimporteerde rietsoorten. Archief Suikerindustrie Nederlands-Indie 1934: 141-166.

Brenchley R, Spannagl M, Pfeifer M, Barker GL, D'Amore R, Allen AM, McKenzie N, Kramer M, Kerhornou A, Bolser D, Kay S, Waite D, Trick M, Bancroft I, Gu Y, Huo N, Luo MC, Sehgal S, Gill B, Kianian S, Anderson O, Kersey P, Dvorak J, McCombie WR, Hall A, Mayer KF, Edwards KJ, Bevan MW and Hall N (2012) Analysis of the bread wheat genome using whole-genome shotgun sequencing. Nature 491: 705-710.
Burner DM (1991) Cytogenetic analyses of sugarcane relatives (Andropogoneae: Saccharinae). Euphytica 54: 125-133.

Cai X, Zhang X and Wang D (2011) Land availability for biofuel production. Environmental Science and Technology 45: 334-339.

Celarier RP (1956) Cytotaxonomy of the Andropogoneae I Subtribes Dimeriinae and Saccharinae. Cytologia 21: 272-291.

Celarier RP and Paliwal RL (1957) Basic chromosome number of four in the subfamily Panicoideae of the Gramineae. Science 126: 1247-1248.

Chen C-C and Hsu C-C (1962) Cytological studies on Taiwan grasses (2): chromosome numbers of some miscellaneous tribes. Journal of Japanese Botany 37: 12-25.

Chen SL and Renvoize SA (2006) Miscanthus. Flora of China 22: $581-583$.

Chiang Y-C, Chou C-H, Huang S and Chiang T-Y (2003) Possible consequences of fungal contamination on the RAPD fingerprinting in Miscanthus (Poaceae). Australian Journal of Botany 51: 197.

Chou C-H (2009) Miscanthus plants used as an alternative biofuel material: the basic studies on ecology and molecular evolution. Renewable Energy 34: 1908-1912.

Chou C-H and Chang F-C (1988) Population study of Miscanthus floridulus II. Ecotypic variation of M. floridulus and M. transmorrisonensis as affected by altitude in Nantou, Taiwan. Botanical Bulletin Academia Sinica 29: 301-314.

Chou C-H and Ueng J-J (1992) Phylogenetic relationship among species of Miscanthus populations in Taiwan. Botanical Bulletin Academia Sinica 33: 63-73.

Chou C-H, Hwang S and Chang F-C (1987) Population study of Miscanthus floridulus (Labill.) Warb. 1. Variation of peroxidase and esterase in 27 populations in Taiwan. Botanical Bulletin Academia Sinica 28: 247-281.

Chou C-H, Chiang Y-C and Chiang T-Y (2000) Genetic variability of Miscanthus sinensis var. condensatus based on RAPD fingerprints. Canadian Journal of Botany 78: 1262-1268.

Chouvarine P, Cooksey AM, McCarthy FM, Ray DA, Baldwin BS, Burgess SC and Peterson DG (2012) Transcriptome-based differentiation of closely-related Miscanthus lines. PloS One 7: e29850.

Chramiec-Głąbik A, Grabowska-Joachimiak A, Sliwinska E, Legutko J and Kula A (2012) Cytogenetic analysis of Miscanthus $\times$ giganteus and its parent forms. Caryologia 65: $234-242$.

Church GL (1929) Meiotic phenomena in certain Gramineae. II. Paniceae and Andropogoneae. Botanical Gazette 88: 63-84.

Clark LV, Brummer JE, Głowacka K, Hall M, Heo K, Long SP, Peng J, Yamada T, Yoo JH, Yu CY, Zhao H and Sacks EJ (2014) A footprint of past global climate change on the population genetic structure of Miscanthus sinensis. Annals of Botany 144: 97-107.

Clayton WD and Renvoize SA (1986) Genera Graminum, Grasses of the World. Kew Bulletin Additional Series XIII. UK, Kew Publishing.

Clayton WD, Vorontsova MS, Harman KT and Williamson $\mathrm{H}$ (2006 onwards) GrassBase - the online world grass flora. Available at http://www.kew.org/data/grasses-db.html

Clifton-Brown JC and Jones MB (1997) The thermal response of leaf extension rate in genotypes of the C4-grass Miscanthus: an important factor in determining the potential productivity of different genotypes. Journal of Experimental Botany 48: 1573-1581.

Clifton-Brown JC and Lewandowski I (2000) Overwintering problems of newly established Miscanthus plantations 
can be overcome by identifying genotypes with improved rhizome cold tolerance. New Phytologist 148: 287-294.

Clifton-Brown JC and Lewandowski I (2002) Screening Miscanthus genotypes in field trials to optimise biomass yield and quality in Southern Germany. European Journal of Agronomy 16: 97-110.

Clifton-Brown JC, Lewandowski I, Andersson B, Basch G, Christian DG, Kjeldsen JB, Jørgensen U, Mortensen JV, Riche AB, Schwarz KU, Tayebi K and Teixeira F (1999) Performance of 15 Miscanthus genotypes at five sites in Europe. Agronomy Journal 93: 1013-1020.

Clifton-Brown JC, Lewandowski I, Bangerth $\mathrm{F}$ and Jones MB (2002) Comparative responses to water stress in staygreen, rapid- and slow senescing genotypes of the biomass crop, Miscanthus. New Phytologist 154: 335-345.

Clifton-Brown JC, Chiang YC and Hodkinson TR (2008) Miscanthus genetic resources and breeding potential. In: Vermerris W (ed.) Genetic Improvement of Bioenergy Crops. New York: Springer Science, pp. 273-290.

Cope TA (1982) Poaceae. In: Nasir E and Ali SI (eds) Flora of Pakistan. No. 143. Karachi: University of Karachi Press, pp. 678.

Crossa J, Beyene Y, Kassa S, Pérez P, Hickey JM, Chen C, G, Burgueño J, Windhausen VS, Buckler E, Jannink JL, Lopez Cruz MA and Babu R (2013) Genomic prediction in maize breeding populations with genotyping-bysequencing. G3 3: 1903-1926.

Daniels J and Roach BT (1987) Taxonomy and evolution. In: Heinz DJ (ed.) Sugarcane Improvement Through Breeding. New York: Elsevier, pp. 7-84.

De Cesare M (2012) Characterisation of Miscanthus genetic resources: a combined analysis of plastid and nuclear microsatellites, nrDNA sequences, flow cytometry and morphology, PhD Thesis. University of Dublin, Trinity College Dublin, Ireland

De Cesare M, Hodkinson TR and Barth S (2010) Chloroplast DNA markers (cpSSRs, SNPs) for Miscanthus, Saccharum and related grasses (Panicoideae, Poaceae). Molecular Breeding 26: 539-544.

De Souza AP, Arundale RA, Dohleman FG, Long SP and Buckeridge MS (2013) Will the exceptional productivity of Miscanthus $\times$ giganteus increase further under rising atmospheric CO2? Agricultural and Forest Meteorology 171-172: 82-92.

Donnelly A, Styles D, Fitzgerald J and Finnan J (2011) A proposed framework for determining the environmental impact of replacing agricultural grassland with Miscanthus in Ireland. GCB Bioenergy 3: 247-263.

Dwiyanti MS, Stewart JR, Nishiwaki A and Yamada T (2014) Natural variation in Miscanthus sinensis seed germination under low temperatures Grassland Science, doi:10.1111/ grs. 12051

Farrell AD, Clifton-Brown JC, Lewandowski I and Jones MB (2006) Frost tolerance and thermal response of leaf growth in four Miscanthus genotypes. The impact of genotypic variation on potential yield. Annals of Applied Biology 149: 337-345.

Fedorov AA (1969) Chromosome numbers of flowering plants. Leningrad, Russia: Nauka.

Feltus FA and Vandenbrink JP (2012) Bioenergy grass feedstock: current options and prospects for trait improvement using emerging genetic, genomic, and systems biology toolkits. Biotechnology for Biofuels 5: 80.

Feng XP, Lourgant K, Castric V, Saumitou-Laprade P, Zheng BS, Jiang D M and Brancourt-Hulmel M (2014) The discovery of natural accessions related to Miscanthus $\times$ giganteus using chloroplast DNA. Crop Science 54: 1645-1655.

Gauder M, Graeff-Hönninger S, Lewandowski I and Claupein W (2012) Long-term yield and performance of 15 different Miscanthus genotypes in southwest Germany. Annals of Applied Biology 160: 126-136.

Gilliand HB (1971) Grasses of Malaya. A Revised Flora of Malaya. vol. III. Singapore: Government Printer, Botanic Garden Singapore, pp. 217.

Głowacka K (2011) A review of the genetic study of the energy crop Miscanthus. Biomass and Bioenergy 35: 2445-2454.

Głowacka K, Jeżowski S and Kaczmarek Z (2009) Polyploidization of Miscanthus sinensis and Miscanthus $\times$ giganteus by plant colchicine treatment. Industrial Crops and Products 30: 444-446.

Głowacka K, Jeżowski S and Kaczmarek Z (2010a) In vitro induction of polyploidy by colchicine treatment of shoots and preliminary characterisation of induced polyploids in two Miscanthus species. Industrial Crops and Products 32: 88-96.

Głowacka K, Jeżowski S and Kaczmarek Z (2010b) Impact of colchicine application during callus induction and shoot regeneration on micropropagation and polyploidisation rates in two Miscanthus species. In Vitro Cellular and Developmental Biology - Plant 46: 161-171.

Głowacka K, Kaczmarek Z and Jeżowski S (2012) Androgenesis in the bioenergy plant: from calli induction to plant regeneration. Crop Science 52: 2659.

Głowacka K, Adhikari S, Peng J, Gifford J, Juvik JA, Long SP and Sacks EJ (2014a) Variation in chilling tolerance for photosynthesis and leaf extension growth among genotypes related to the C4 grass Miscanthus $\times$ giganteus. Journal of Experimental Botany, doi:10.1093/jxb/eru287.

Głowacka K, Clark LV, Adhikari S, Peng J, Stewart JR, Nishiwaki A, Yamada T, Jørgensen U, Hodkinson TR, Gifford J, Juvik JA and Sacks EJ (2014b) Genetic variation in Miscanthus $\times$ giganteus and the importance of estimating genetic distance thresholds for differentiating clones. $G C B$ Bioenergy, doi:10.1111/gcbb.12166.

Goff SA, Ricke D, Lan TH, Presting G, Wang R, Dunn M, Glazebrook J, Sessions A, Oeller P, Varma H, Hadley D, Hutchison D, Martin C, Katagiri F, Lange BM, Moughamer T, Xia Y, Budworth P, Zhong J, Miguel T, Paszkowski U, Zhang S, Colbert M, Sun WL, Chen L, Cooper B, Park S, Wood TC, Mao L, Quail P, Wing R, Dean R, Yu Y, Zharkikh A, Shen R, Sahasrabudhe S, Thomas A, Cannings R, Gutin A, Pruss D, Reid J, Tavtigian S, Mitchell J, Eldredge G, Scholl T, Miller RM, Bhatnagar S, Adey N, Rubano T, Tusneem N, Robinson R, Feldhaus J, Macalma T, Oliphant A and Briggs S (2002) A draft sequence of the rice genome (Oryza sativa L. ssp. japonica). Science 296: 92-100.

Gopalakrishnan G, Cristina Negri M and Snyder SW (2013) A novel framework to classify marginal land for sustainable biomass feedstock production. Journal of Environmental Quality 40: 1593-1600.

Greef J, Deuter M, Jung C and Schondelmaier J (1997) Genetic diversity of European Miscanthus species revealed by AFLP fingerprinting. Genetic Resources and Crop Evolution 44: $185-195$.

Hastings A, Clifton-Brown JC, Wattenbach M, Stampfl P, Mitchell CP and Smith P (2008) Potential of Miscanthus grasses to provide energy and hence reduce greenhouse gas emissions. Agronomy for Sustainable Development 28: $465-472$. 
Hernández P, Dorado G, Laurie Da, Martín A and Snape JW (2001) Microsatellites and RFLP probes from maize are efficient sources of molecular markers for the biomass energy crop Miscanthus. Theoretical and Applied Genetics 102: 616-622.

Hirayoshi I, Nishikawa K, Kubona M and Sakaida T (1959) Cyto-genetical studies on forage plants (VII) chromosome conjugation and fertility of Miscanthus hybrids including $M$. sinensis, $M$. sinensis var. condensatus and $M$. tinctorius. Research Bulletin Faculty Agriculture Gifu University 11: 86-91.

Ho C-W, Wu T-H, Hsu T-W, Huang J-C, Huang C-C and Chiang T-Y (2011) Development of 12 genic microsatellite loci for a biofuel grass, Miscanthus sinensis (Poaceae). American Journal of Botany 98: e201-e203.

Hodgson EM, Lister SJ, Bridgwater AV, Clifton-Brown JC and Donnison IS (2010) Genotypic and environmentally derived variation in the cell wall composition of Miscanthus in relation to its use as a biomass feedstock. Biomass and Bioenergy 34: 652-660.

Hodgson EM, Nowakowski DJ, Shield I, Riche A, Bridgwater AV, Clifton-Brown JC and Donnison IS (2011) Variation in Miscanthus chemical composition and implications for conversion by pyrolysis and thermo-chemical bio-refining for fuels and chemicals. Bioresource Technology 102: $3411-3418$.

Hodkinson TR (2011) Integrating ecology and systematics in climate change research. In: Hodkinson TR, Jones MB, Waldren S and Parnell JAN (eds) Climate Change, Ecology and Systematics. Systematics Association Special Volume 78. Cambridge University Press, Cambridge, UK.

Hodkinson TR and Renvoize SA (2001) Nomenclature of Miscanthus $\times$ giganteus (Poaceae). Kew Bulletin 56: 759-760.

Hodkinson TR, Chase MW and Renvoize SA (1997) Systematics of Miscanthus. Aspects of Applied Biology 49: 189-198.

Hodkinson TR, Chase MW and Renvoize SA (2001) Genetic resources of Miscanthus. Aspects of Applied Biology 65: $239-248$.

Hodkinson TR, Renvoize SA and Chase MW (2002a) Characterization of a genetic resource collection for Miscanthus (Saccharinae, Andropogoneae, Poaceae) using AFLP and ISSR PCR. Annals of Botany 89: 627-636.

Hodkinson TR, Chase MW, Lledó D, Salamin N and Renvoize SA (2002b) Phylogenetics of Miscanthus, Saccharum and related genera (Saccharinae, Andropogoneae, Poaceae) based on DNA sequences from ITS nuclear ribosomal DNA. Journal of Plant Research 115: 381-392.

Hodkinson TR, Chase MW, Takahashi C, Leitch I, Bennett MD and Renvoize SA (2002c) The use of DNA sequencing (ITS and $t r n L-F$ ), AFLP, and fluorescent in situ hybridization to study allopolyploid Miscanthus (Poaceae). American Journal of Botany 89: 279-286.

Hodkinson TR, De Cesare M and Barth S (2013) Nuclear SSR markers for Miscanthus, Saccharum, and related grasses (Saccharinae, Poaceae). Applications in Plant Sciences 1: 1300042.

Hu X, Diao Y, Zheng X, Qu Z, Zhou F and Hu Z (2012) Isolation and characterization of simple sequence repeat loci in Miscanthus floridulus and their potential use as markers in related species. Biomass and Bioenergy 46: 801-804.

Hung K-H, Chiang T-Y, Chiu C-T, Hsu T-W and Ho C-W (2009) Isolation and characterization of microsatellite loci from a potential biofuel plant Miscanthus sinensis (Poaceae). Conservation Genetics 10: 1377-1380.
Hunter AWS (1930) A karyosystematic investigation in the Gramineae. Canadian Journal of Research (C) 11: 213-241.

Ibaragi Y, Lim SH, Yook MJ, Chang CS and Kim DS (2013) Taxonomic notes on Korean Miscanthus $\times$ ogiformis Honda (Poaceae) - a new record from Korea. Journal of Japanese Botany 88: 184-187.

International Brachypodium Initiative (2010) Genome sequencing and analysis of the model grass Brachypodium distachyon. Nature 463: 763-768.

IPNI (2014) The Plant Names Project. International Plant Names Index. http://www.ipni.org

Iwata H, Kamijo T and Tsumura Y (2004) Genetic structure of Miscanthus sinensis ssp. condensatus (Poaceae) on Miyake Island: implications for revegetation of volcanically devastated sites. Ecological Research 20: 233-238.

Jensen EF (2009) Flowering time diversity in Miscanthus: a tool for the optimisation of biomass. Comparative Biochemistry and Physiology Part A: Molecular and Integrative Physiology 153: S197.

Jensen E, Farrar K, Thomas-Jones S, Hastings A, Donnison I and Clifton-Brown J (2011) Characterization of flowering time diversity in Miscanthus species. GCB Bioenergy 3: $387-400$.

Jeżowski S, Głowacka K and Kaczmarek Z (2011) Variation on biomass yield and morphological traits of energy grasses from the genus Miscanthus during the first years of crop establishment. Biomass and Bioenergy 35: 814-821.

Jiang J-X, Wang Z-H, Tang B-R, Xiao L, Ai X and Yi Z-L (2012) Development of novel chloroplast microsatellite markers for Miscanthus species (Poaceae). American Journal of Botany 99: e230-e233.

Jing Q, Conijn SJG, Jongschaap REE and Bindraban PS (2012) Modeling the productivity of energy crops in different agro-ecological environments. Biomass and Bioenergy 46: $618-633$.

Jones MB and Walsh M (2001) Miscanthus for Energy and Fibre. London: James and James Ltd, The Cromwell Press, p. 192.

Jones MB, Finnan J and Hodkinson TR (2014) Morphological and physiological traits for higher biomass production in perennial rhizomatous grasses grown on marginal land GCB Bioenergy (in press)

Jørgensen U (1997) Genotypic variation in dry matter accumulation and content of $\mathrm{N}, \mathrm{K}$ and $\mathrm{Cl}$ in Miscanthus in Denmark. Biomass and Bioenergy 12: 155-169.

Jørgensen U (2011) Benefits versus risks of growing biofuel crops: the case of Miscanthus. Current Opinion in Environmental Sustainability 3: 24-30.

Kaack K, Schwarz K-U and Brander PE (2003) Variation in morphology, anatomy and chemistry of stems of Miscanthus genotypes differing in mechanical properties. Industrial Crops and Products 17: 131-142.

Kellogg EA (2013) Phylogenetic relationships of Saccharinae and Sorghinae. In Genomics of the Saccharinae. Ed. Paterson AH. Plant Genetics and Genomics: Crops and Models 11: 3-21.

Kim C, Zhang D, Auckland SA, Rainville LK, Jakob K, Kronmiller B, Sacks EJ, Deuter M and Paterson AH (2012) SSR-based genetic maps of Miscanthus sinensis and M. sacchariflorus, and their comparison to sorghum. Theoretical and Applied Genetics. 124: 1325-1338.

Kim C, Lee T-H, Guo H, Chung SJ, Paterson AH, Kim D-S and Lee G-J (2014) Sequencing of transcriptomes from two Miscanthus species reveals functional specificity in 
rhizomes, and clarifies evolutionary relationships. $B M C$ Plant Biology 14: 134 , doi:10.1186/1471-2229-14-134.

Koyama T (1987) Grasses ofJapan and its Neighboring Regions: An Identification Manual. Tokyo: Kodansha, Ltd, p. 370.

Lafferty J and Lelley T (1994) Cytogenetic studies of different Miscanthus species with potential for agricultural use. Plant Breeding 113: 246-249.

Lee YN (1964a) Taxonomic studies on the genus Miscanthus: relationships among the section, subsection and species, part 1. Journal of Japanese Botany 39: 196-205.

Lee YN (1964b) Taxonomic studies on the genus Miscanthus: relationships among the section, subsection and species, part 2. Journal of Japanese Botany 39: 257-265.

Lee YN (1964c) Taxonomic studies on the genus Miscanthus: relationships among the section, subsection and species, part 3. Journal of Japanese Botany 39: 289-298.

Lee YN (1964d) Taxonomic studies on the genus Miscanthus: anatomical patterns of leaves. Botanical Magazine (Tokyo) 77: 122-130.

Leitch IJ, Hanson L, Lim KY, Kovarik A, Chase MW, Clarkson JJ and Leitch AR (2008) The ups and downs of genome size evolution in polyploid species of Nicotiana (Solanaceae). Annals of Botany 101: 805-814.

Li HW and Ma TH (1951) Cytological studies of sugarcane and its relatives VIII. Accessory chromosomes of Miscanthus japonicus, Anders. In: Hughes CG (ed.) Proceedings of the Seventh Congress of the International Society of Sugar Cane Technologists. Brisbane: Executive Committee ISSCT, pp. $277-285$.

Li HW, Shang KC, Hsiao YY and Yong PC (1959) Cytological studies of sugarcane and its relatives, XVI. Basic chromosome number of Saccharunn officinarum L. Cytologia 24: 220-36.

Li HW, Loh CS and Lee CL (1948) Cytological studies on sugarcane and its relatives 1. Hybrids between Saccharum officinarum, Miscanthus japonicus and Saccharum spontaneum. Botanical Bulletin of Academia Sinica 2: 147-160.

Li Xi, Hu D, Luo M, Zhu M, Li Xinwei, Luo F, Li J and Yan J (2013) Nuclear DNA content variation of three Miscanthus species in China. Genes and Genomics 35: 13-20.

Linde-Laursen IB (1993) Cytogenetic analysis of Miscanthus 'Giganteus', an interspecific hybrid. Hereditas 119: 297-300.

Lledó MD, Renvoize SA and Chase MW (2001) Miscanthus sinensis and Miscanthus sacchariflorus: a confusing pair of species. Aspects of Applied Biology 65: 249-254.

Ma X-F, Jensen E, Alexandrov N, Troukhan M, Zhang L, ThomasJones S, Farrar K, Clifton-Brown J, Donnison I, Swaller T and Flavell R (2012) High resolution genetic mapping by genome sequencing reveals genome duplication and tetraploid genetic structure of the diploid Miscanthus sinensis. PLoS One 7: e33821.

Matlaga DP, Quinn LD, Davis AS and Stewart JR (2012) Light response of native and introduced Miscanthus sinensis seedlings. Invasive Plant Science and Management 5: 363-374.

Mehra PN, Khosla PK, Kohli BL and Koonar JS (1968) Cytological studies in the North Indian Grasses (part I). Research Bulletin Punjab University 19: 157-230.

Meyer MH, Paul J and Anderson NO (2010) Competitive ability of invasive Miscanthus biotypes with aggressive switchgrass. Biological Invasions 12: 3809-3816.

Myles S, Peiffer J, Brown PJ, Ersoz ES, Zhanga Z, Costicha DE and Buckler ES (2009) Association mapping: critical considerations shift from genotyping to experimental design. The Plant Cell 21: 2194-2202.
Nielsen PN (1990) Elefantengrassanbau in Danemark - Praktikerbericht. Pflug und Spaten 3: 1-4.

Nijsen M, Smeets E, Stehfest E and Vuuren DP (2012) An evaluation of the global potential of bioenergy production on degraded lands. GCB Bioenergy 4: 130-147.

Nishiwaki A, Mizuguti A, Kuwabara S, Toma Y, Ishigaki G, Miyashita T, Yamada T, Matuura H, Yamaguchi S, Rayburn AL, Akashi R and Stewart JR (2011) Discovery of natural Miscanthus (Poaceae) triploid plants in sympatric populations of Miscanthus sacchariflorus and Miscanthus sinensis in southern Japan. American Journal of Botany 98: $154-159$.

Osada T (1993) Illustrated Grasses of Japan. Tokyo: Heibonsia Ltd, pp. 158-205.

Paterson AH, Bowers JE, Bruggmann R, Dubchak I, Grimwood J, Gundlach H, Haberer G, Hellsten U, Mitros T, Poliakov A, Schmutz J, Spannagl M, Tang H, Wang X, Wicker T, Bharti AK, Chapman J, Feltus FA, Gowik U, Grigoriev IV, Lyons E, Maher CA, Martis M, Narechania A, Otillar RP, Penning BW, Salamov AA, Wang Y, Zhang L, Carpita NC, Freeling M, Gingle AR, Hash CT, Keller B, Klein P, Kresovich S, McCann MC, Ming R, Peterson DG, Mehboobur-Rahman, Ware D, Westhoff P, Mayer KF, Messing J and Rokhsar DS (2009) The Sorghum bicolor genome and the diversification of grasses. Nature 457: 551-556.

Pellicer J, Fay MF and Leitch IJ (2010) The largest eukaryotic genome of them all? Botanical Journal of the Linnean Society 164: 10-15.

Perera D, Baldwin BS and Reichert N (2013) Tissue culture and induced mutation of giant Miscanthus. In Vitro Cellular and Developmental Biology - Animal 48: 42.

Petersen KK, Hagberg P and Kristiansen K (2002) In vitro chromosome doubling of Miscanthus sinensis. Plant Breeding 121: 445-450.

Petersen KK, Hagberg P and Kristiansen K (2003) Colchicine and oryzalin mediated chromosome doubling in different genotypes of Miscanthus sinensis. Plant Cell, Tissue and Organ Culture 73: 137-146.

Price S (1963a) Accessory chromosomes in Miscanthus floridulus. Journal of Heredity 54: 13-16.

Price S (1963b) Cytogenetics of modern sugarcanes. Economic Botany 17: 97-106.

Price S and Daniels J (1968) Cytology of South Pacific sugarcane and related grasses: with special reference to Fiji. Journal of Heredity 59: 141-145.

Qin Z, Zhuang Q, Zhu X, Cai X and Zhang X (2011) Carbon consequences and agricultural implications of growing biofuel crops on marginal agricultural lands in China. Environmental Science and Technology 45: 10765-10772.

Quinn LD, Allen DJ and Stewart JR (2010) Invasiveness potential of Miscanthus sinensis: implications for bioenergy production in the United States. GCB Bioenergy 2: $310-320$.

Quinn LD, Matlaga DP, Stewart JR and Davis AS (2011) Empirical evidence of long-distance dispersal in Miscanthus sinensis and Miscanthus $\times$ giganteus. Invasive Plant Science and Management 4: 142-150.

Quinn LD, Culley TM and Stewart JR (2012) Genetic comparison of introduced and native populations of Miscanthus sinensis (Poaceae), a potential bioenergy crop. Grassland Science 58: 101-111.

Rayburn AL, Crawford J, Rayburn CM and Juvik JA (2009) Genome size of three Miscanthus species. Plant Molecular Biology Reporter 27: 184-188. 
Robson P, Mos M, Clifton-Brown JC and Donnison IS (2011) Phenotypic variation in senescence in Miscanthus: towards optimising biomass quality and quantity. BioEnergy Research 5: 95-105.

Sang T (2011) Toward the domestication of lignocellulosic energy crops: learning from food crop domestication. Journal of Integrative Plant Biology 53: 96-104.

Sang T and Zhu W (2011) China's bioenergy potential. GCB Bioenergy 3: 79-90.

Scally L (2001) Miscanthus, PhD Thesis. University of Dublin, Trinity College Dublin, Ireland

Scally L, Hodkinson TR and Jones MB (2001a) Origins and taxonomy of Miscanthus. In: Jones MB, Walsh M (eds) Miscanthus for Energy and Fibre. London, UK. James and James Ltd, The Cromwell Press. pp 1-9.

Scally L, Waldren S, Hodkinson TR and Jones MB (2001b) Morphological and molecular systematics of the genus Miscanthus. Aspects of Applied Biology 65: 231-237.

Schnable PS, Ware D, Fulton RS, Stein JC, Wei F, Pasternak S, Liang C, Zhang J, Fulton L, Graves TA, Minx P, Reily AD, Courtney L, Kruchowski SS, Tomlinson C, Strong C, Delehaunty K, Fronick C, Courtney B, Rock SM, Belter E, Du F, Kim K, Abbott RM, Cotton M, Levy A, Marchetto P, Ochoa K, Jackson SM, Gillam B, Chen W, Yan L, Higginbotham J, Cardenas M, Waligorski J, Applebaum E, Phelps L, Falcone J, Kanchi K, Thane T, Scimone A, Thane N, Henke J, Wang T, Ruppert J, Shah N, Rotter K, Hodges J, Ingenthron E, Cordes M, Kohlberg S, Sgro J, Delgado B, Mead K, Chinwalla A, Leonard S, Crouse K, Collura K, Kudrna D, Currie J, He R, Angelova A, Rajasekar S, Mueller T, Lomeli R, Scara G, Ko A, Delaney K, Wissotski M, Lopez G, Campos D, Braidotti M, Ashley E, Golser W, Kim H, Lee S, Lin J, Dujmic Z, Kim W, Talag J, Zuccolo A, Fan C, Sebastian A, Kramer M, Spiegel L, Nascimento L, Zutavern T, Miller B, Ambroise C, Muller S, Spooner W, Narechania A, Ren L, Wei S, Kumari S, Faga B, Levy MJ, McMahan L, Van Buren P, Vaughn MW, Ying K, Yeh CT, Emrich SJ, Jia Y, Kalyanaraman A, Hsia AP, Barbazuk WB, Baucom RS, Brutnell TP, Carpita NC, Chaparro C, Chia JM, Deragon JM, Estill JC, Fu Y, Jeddeloh JA, Han Y, Lee H, Li P, Lisch DR, Liu S, Liu Z, Nagel DH, McCann MC, SanMiguel P, Myers AM, Nettleton D, Nguyen J, Penning BW, Ponnala L, Schneider KL, Schwartz DC, Sharma A, Soderlund C, Springer NM, Sun Q, Wang H, Waterman M, Westerman R, Wolfgruber TK, Yang L, Yu Y, Zhang L, Zhou S, Zhu Q, Bennetzen JL, Dawe RK, Jiang J, Jiang N, Presting GG, Wessler SR, Aluru S, Martienssen RA, Clifton SW, McCombie WR, Wing RA and Wilson RK (2009) The B73 maize genome: complexity, diversity, and dynamics. Science 326: 1112-1115.

Sede S, Escobar A, Morrone O and Zuloaga FO (2010) Chromosome studies in American Paniceae (Poaceae, Panicoideae). Annals of the Missouri Botanic Garden 97: $128-138$.

Shimono Y, Kurokawa S, Nishida T, Ikeda H and Futagami N (2013) Phylogeography based on intraspecific sequence variation in chloroplast DNA of Miscanthus sinensis (Poaceae), a native pioneer grass in Japan. Botany 91: 449-456.

Slavov GT, Nipper R, Robson P, Farrar K, Allison GG, Bosch M, Clifton-Brown JC, Donnison IS and Jensen E (2014) Genome-wide association studies and prediction of 17 traits related to phenology, biomass and cell wall composition in the energy grass Miscanthus sinensis. New Phytologist 201: 1227-1239.
Słomka A, Kuta E, Płażek A, Dubert F, Żur I, Dubas E, Kopeć P and Żurek G (2012) Sterility of Miscanthus $\times$ giganteus results from hybrid incompatibility. Acta Biologica Cracoviensia Series Botanica 54: 5-6.

Suman A, Ali K, Arro J, Parco AS, Kimbeng CA and Baisakh N (2011) Molecular diversity among members of the Saccharum complex assessed using TRAP markers based on lignin-related genes. BioEnergy Research 5: 197-205.

Sun Q, Lin Q, Yi Z-L, Yang Z- R and Zhou F-S (2010) A taxonomic revision of Miscanthus s.l. (Poaceae) from China. Botanical Journal of the Linnean Society 164: 178-220.

Swaminathan K, Alabady MS, Varala K, De Paoli E, Ho I, Rokhsar Dan S, Arumuganathan AK, Ming R, Green PJ, Meyers BC, Moose SP and Hudson ME (2010) Genomic and small RNA sequencing of Miscanthus $\times$ giganteus shows the utility of sorghum as a reference genome sequence for Andropogoneae grasses. Genome biology 11: R12.

Swaminathan K, Chae WB, Mitros T, Varala K, Xie L, Barling A, Glowacka K, Hall M, Jezowski S, Ming R, Hudson M, Juvik JA, Rokhsar Daniel S and Moose SP (2012) A framework genetic map for Miscanthus sinensis from RNAseqbased markers shows recent tetraploidy. BMC genomics 13: 142 .

Teerawatananon A, Jacobs SWL and Hodkinson TR (2011) Phylogenetics of Panicoideae (Poaceae) based on chloroplast and nuclear DNA sequences. Telopea 13: $115-142$.

Touchell DH and Ranney TG (2012) Chromosome doubling and fertility restoration in Miscanthus $\times$ giganteus. Hortscience 47: S334.

Von Wühlisch G, Deuter M and Muhs H-J (1994) Identifizierung verschieder Miscanthus-sorten mittels isoenzymem. Journal of Agronomy and Crop Science 172: 247-254.

Wang X, Yamada Tetsuya, Kong F-J, Abe Y, Hoshino Y, Sato H, Takamizo T, Kanazawa A and Toshihiko Y (2011) Establishment of an efficient in vitro culture and particle bombardment-mediated transformation systems in Miscanthus sinensis Anderss., a potential bioenergy crop. GCB Bioenergy 3: 322-332.

Weng J and Ueng R (1997) Effect of temperature on photosynthesis of Miscanthus clones collected from different elevations. Photosynthetica 34: 307-311.

Xie G and Peng L (2011) Genetic engineering of energy crops: a strategy for biofuel production in China. Journal of Integrative Plant Biology 53: 143-150.

Xu S (2013) Genetic mapping and genomic selection using recombination breakpoint data. Genetics 195: 1103-1115.

Yan J, Chen W, Luo F, Ma H, Meng A, Li X, Zhu M, Li S, Zhou H, Zhu W, Han B, Ge S, Li J and Sang T (2012) Variability and adaptability of Miscanthus species evaluated for energy crop domestication. GCB Bioenergy 4: 49-60.

Yu CY, Kim HS, Rayburn AL, Widholm JM and Juvik JA (2009) Chromosome doubling of the bioenergy crop, Miscanthus $\times$ giganteus. GCB Bioenergy 1: 404-412.

Yu J, Zhao H, Zhu T, Chen L and Peng J (2013) Transferability of rice SSR markers to Miscanthus sinensis, a potential biofuel crop. Euphytica 191: 455-468.

Zhang T, Wyman CE, Jakob K and Yang B (2012) Rapid selection and identification of Miscanthus genotypes with enhanced glucan and xylan yields from hydrothermal pretreatment followed by enzymatic hydrolysis. Biotechnology for Biofuels 5: 56.

Zhang D, Guo H, Kim C, Lee T-H, Li J, Robertson J, Wang X, Wang Z and Paterson AH (2013a) CSGRqtl, a comparative 
quantitative trait locus database for Saccharinae grasses. Plant Physiology 161: 594-599.

Zhang QX, Shen YK, Shao RX, Fang J, He YQ, Ren JX, Zheng BS and Chen GJ (2013b) Genetic diversity of natural Miscanthus sinensis populations in China revealed by ISSR markers. Biochemical Systematics and Ecology 48: 248-256.

Zhao H, Wang B, He J, Yang J, Pan L, Sun D and Peng J (2013a) Genetic diversity and population structure of Miscanthus sinensis germplasm in China. PLoS One 8: e75672.

Zhao H, Li Q, He J, Yu J, Yang J, Liu C and Peng J (2013b) Genotypic variation of cell wall composition and its conversion efficiency in Miscanthus sinensis, a potential biomass feedstock crop in China GCB Bioenergy. doi:10.1111/gcbb.12115

Zhao H, Huai Z, Xiao Y, Wang X, Yu J, Ding G and Peng J (2014) Natural variation and genetic analysis of tiller angle gene MsTAC1 in Miscanthus sinensis. Planta 240: 161-175.
Zhou H-F, Li S-S and Ge S (2011) Development of microsatellite markers for Miscanthus sinensis (Poaceae) and cross-amplfication in other related species. American Journal of Botany 98: e195-e197.

Zub HW and Brancourt-Hulmel M (2010) Agronomic and physiological performances of different species of Miscanthus, a major energy crop. A review. Agronomy for Sustainable Development 30: 201-214.

Zub HW, Arnoult S, Younous J, Lejeune-Hénaut I and BrancourtHulmel M (2012) The frost tolerance of Miscanthus at the juvenile stage: differences between clones are influenced by leaf-stage and acclimation. European Journal of Agronomy 36: 32-40.

Zur I, Dubas E, Słomka A, Dubert F, Kuta E and Płazek A (2013) Failure of androgenesis in Miscanthus $\times$ giganteus in vitro culture of cytologically unbalanced microspores. Plant Reproduction 26: 297-307. 